OPEN ACCESS

Edited by:

Honoo Satake,

Suntory Foundation for

Life Sciences, Japan

Reviewed by:

Rafael Henrique Nóbrega,

Universidade Estadual Paulista Júlio de Mesquita Filho (UNESP), Brazil

Shinji Kanda,

The University of Tokyo, Japan

*Correspondence: José A. Muñoz-Cueto

munoz.cueto@uca.es

Specialty section:

This article was submitted to Experimental Endocrinology, a section of the journal

Frontiers in Endocrinology

Received: 24 August 2017 Accepted: 10 October 2017 Published: 30 October 2017

Citation:

Muñoz-Cueto JA, PaulladaSalmerón JA, Aliaga-Guerrero M, Cowan ME, Parhar IS and Ubuka T

(2017) A Journey through the Gonadotropin-Inhibitory Hormone System of Fish.

Front. Endocrinol. 8:285. doi: 10.3389/fendo.2017.00285

\section{A Journey through the Gonadotropin-Inhibitory Hormone System of Fish}

\author{
José A. Muñoz-Cueto ${ }^{1,2 *}$, José A. Paullada-Salmerón ${ }^{1,2}$, María Aliaga-Guerrero ${ }^{1,2}$, \\ Mairi E. Cowan ${ }^{1,2}$, Ishwar S. Parhar ${ }^{3}$ and Takayoshi Ubuka ${ }^{3}$
}

${ }^{1}$ Faculty of Environmental and Marine Sciences, Department of Biology, University of Cádiz, Marine Campus of International Excellence (CEIMAR) and Agrifood Campus of International Excellence (ceiA3), Puerto Real, Spain, ${ }^{2}$ Marine Research Institute (INMAR) - Andalusian Centre of Marine Science and Technology (CACYTMAR), University of Cádiz, Puerto Real, Spain, ${ }^{3}$ Jeffrey Cheah School of Medicine and Health Science, Brain Research Institute, Monash University Malaysia, Bandar Sunway, Malaysia

Gonadotropin-inhibitory hormone $(\mathrm{GnlH})$ is a hypothalamic neuropeptide that belongs to the RFamide peptide family and was first identified in the quail brain. From the discovery of avian $\mathrm{GnlH}$, orthologous $\mathrm{GnlH}$ peptides have been reported in a variety of vertebrates, including mammals, amphibians, teleosts and agnathans, but also in protochordates. It has been clearly established that $\mathrm{G} n \mathrm{HH}$ suppresses reproduction in avian and mammalian species through its inhibitory actions on brain $\mathrm{GnRH}$ and pituitary gonadotropins. In addition, GnlH also appears to be involved in the regulation of feeding, growth, stress response, heart function and social behavior. These actions are mediated via G protein-coupled $\mathrm{GnlH}$ receptors (GnlH-Rs), of which two different subtypes, GPR147 and GPR74, have been described to date. With around 30,000 species, fish represent more than one-half of the total number of recognized living vertebrate species. In addition to this impressive biological diversity, fish are relevant because they include model species with scientific and clinical interest as well as many exploited species with economic importance. In spite of this, the study of $\mathrm{GnIH}$ and its physiological effects on reproduction and other physiological processes has only been approached in a few fish species, and results obtained are in some cases conflicting. In this review, we summarize the information available in the literature on GnlH sequences identified in fish, the distribution of $\mathrm{GnIH}$ and $\mathrm{GnlH}-\mathrm{Rs}$ in central and peripheral tissues, the physiological actions of $\mathrm{GnIH}$ on the reproductive brain-pituitary-gonadal axis, as well as other reported effects of this neuropeptide, and existing knowledge on the regulatory mechanisms of $\mathrm{GnlH}$ in fish.

Keywords: LPXRFa, gonadotropin-inhibitory hormone, reproduction, teleosts, GnRH, gonadotropins, gonads, behavior

\section{INTRODUCTION}

Gonadotropin-inhibitory hormone $(\mathrm{GnIH})$ is a neuropeptide that was first identified in the Japanese quail (Coturnix japonica) brain and exhibited inhibitory actions on gonadotropin secretion both in vitro (1) and in vivo (2). Following on from pioneer research in avian species, subsequent studies performed in mammals demonstrated that GnIH could also inhibit the reproductive process in this group of vertebrates (3-7). In the last 17 years, GnIH orthologs have been identified not only in tetrapod vertebrates, but also in fish and protochordates (8-10). The ancestral form of $\mathrm{GnIH}$, which has a C-terminal PQRF-amide structure, emerged in the 
amphioxus, a protochordate species (11). However, this ancestral form of $\mathrm{GnIH}$ was duplicated into two paralogous genes, GnIH and NPFF, by chromosome duplication that occurred at the beginning of vertebrate evolution $(12,13)$. NPFF is also expressed in the brain of vertebrates and discussed when relevant in this review.

Fishes, which represent around half of all living vertebrate species, are one of the most successful radiations in the long evolutionary history of vertebrates (14). Almost all ray-finned fishes are teleosts, which represent the dominant vertebrates inhabiting marine and freshwater ecosystems. Fishes include most commercially important species from fisheries and aquaculture, but also several model organisms for genomics, developmental biology and clinical studies. Despite their impressive biological diversity, key phylogenetic position, economic and scientific importance, the study of $\mathrm{GnIH}$ and its physiological effects have been approached in only a few fish species. In addition, the action of $\mathrm{GnIH}$ on gonadotropin secretion and reproduction has conflicting results in fish. For example, Amano et al. (15) reported that goldfish $\mathrm{GnIH}$ stimulated gonadotropin release from cultured sockeye salmon (Oncorhynchus nerka) pituitary cells. On the other hand, Zhang et al. (16) reported that intraperitoneal administration of zebrafish GnIH to goldfish (Carassius auratus) inhibited serum gonadotropin levels. The reason for this discrepancy may be partially because the endogenous GnIH peptides of the fish were not used to show their physiological effects. The nature of $\mathrm{GnIH}$ effects seems to be dependent on the species, as well as on the sex of the animals, the physiological status, dose, the route and the time elapsed after administration of the $\mathrm{GnIH}$ peptide. For example, in vivo stimulatory effects of intraperitoneally injected tilapia GnIH (tiGnIH)-2 on FSH and LH secretion have been reported in female tilapia, Oreochromis niloticus (17) whereas intracerebroventricular (icv) administration of sea bass GnIH (sbGnIH)-2 inhibited $f \operatorname{sh} \beta$ and $\operatorname{lh} \beta$ expression and $\mathrm{LH}$ plasma levels in male European sea bass, Dicentrarchus labrax (18). In goldfish, there are remarkable differences in reproductive responses to $\mathrm{GnIH}$ at different gonadal maturation stages, which reinforce the idea that seasonal reproductive influences are important modulators of $\mathrm{GnIH}$ actions $(19,20)$. Therefore, more efforts on fish $\mathrm{GnIH}$ research appear necessary to obtain a clear picture on the role of this neuropeptide on reproduction and other physiological processes in this important group of vertebrates. This review aims at synthesizing the most relevant information regarding the forms, brain distribution, actions and regulation of fish $\mathrm{GnIH}$ reported up to date in the literature.

\section{COMPARISON OF TELEOST FISH GnIH WITH OTHER VERTEBRATE GnIH ORTHOLOGS}

The comparison of GnIH precursor and GnIH peptide sequences in various teleost fish species as well as the spotted gar, the coelacanth Latimeria chalumnae, the Japanese quail, and humans are presented in Figure 1. In order to identify in this review if the differences in protein or peptide sequences respond to a taxonomic pattern, taxonomic information (Class, Order, Family) of the species analyzed in this figure is provided in Table 1 . The mature structure of quail GnIH that was identified by immunoaffinity chromatography and mass spectrometry is SIKPSAYLPLRFamide (1). The cDNA sequence that encodes the quail GnIH precursor polypeptide was cloned and was found to encompass two further peptide sequences besides $\mathrm{GnIH}$ that have -LPXRFamide (X $=\mathrm{L}$ or Q) sequences at the C-temini. These LPXRFamide peptides were named GnIH-related peptide (RP)-1 and GnIH-RP-2 (21). These three LPXRFamide peptides, GnIH-RP-1, GnIH, GnIH-RP-2 are encoded in the quail $\mathrm{GnIH}$ precursor polypeptide in this order (Figure 1). The mature peptide sequence of GnIH-RP-2, which is SSIQSLLNLPQRFamide, was also identified by immunoaffinity chromatography and mass spectrometry (21) (Figure 1). Later in the year 2000, a cDNA encoding human LPXRFamide peptide precursor polypeptide was found in the gene database (22). Human LPXRFamide peptide precursor encompasses one C-terminal-LPLRFamide peptide and one-LPQRFamide peptide in this order, and these were named human RFamide related peptide (RFRP)-1 and -3, respectively. There is also an LPXRFamide-like peptide sequence named human RFRP-2 which has a C-terminal-LPLRSamide sequence in between human RFRP-1 and -3 in the precursor polypeptide (Figure 1). The structures of the mature human RFRP- 1 and -3 peptides were identified to be MPHSFANLPLPFamide and VPNLPQRFamide by immunoaffinity chromatography and mass spectrometry (23). The alignment of GnIH precursor polypeptides by the European Bioinformatics Institute (EMBL-EBI) Clustal Omega showed that human RFRP-1 and RFRP-2 align with quail GnIH-RP-1 and $\mathrm{GnIH}$, respectively (Figure 1). Human RFRP-3 aligns with an LPXRFamide-like peptide in the quail GnIH precursor, which has a C-terminal-LSNRSamide sequence (Figure 1).

The coelacanth is a lobe-finned fish that is closely related to tetrapods. Three LPXRFamide peptides and one LPXRFamidelike peptide are encoded in the coelacanth (Latimeria chalumnae) GnIH precursor, and they align to human RFRP-1/quail GnIHRP-1, human RFRP-2/quail GnIH, human RFRP-3, and quail GnIH-RP-2 (Figure 1). The spotted gar (Lepisosteus oculatus) is a ray-finned fish that diverged from teleosts before teleost specific genome duplication, and therefore, it is regarded as a good biomedical model (24). Three LPXRFamide peptides are encoded in the gar $\mathrm{GnIH}$ precursor polypeptide and they align to human RFRP-1/quail GnIH-RP-1, human RFRP-2/quail GnIH, and human RFRP-3 (Figure 1). GnIH precursor polypeptides of spotted green pufferfish (Tetraodon nigroviridis), torafugu (Takifugu rubripes), tongue sole (Cynoglossus semilaevis), and European sea bass encode only two LPXRFamide-like peptide sequences, which have C-terminal-MPMRFamide and-MPQRFamide sequences, which align to human RFRP-1/quail GnIH-RP-1 and human RFRP-2/quail GnIH, respectively (Figure 1). $\mathrm{GnIH}$ precursor polypeptides of Nile tilapia, princess cichlid (Neolamprologus brichardi), and Lake Victoria cichlid Pundamilia nyererei encode one LPXRFamide-like and one LPXRFamide peptide sequence, which have C-terminal-MPLRFamide and-LPQRFamide sequences, which align to human RFRP-1/ quail GnIH-RP-1 and human RFRP-2/quail GnIH, respectively (Figure 1). The GnIH precursor of the other teleost fish species encodes three LPXRFamide or LPXRFamide-like peptides and 
Homo sapiens

Coturnix japonica

Latimeria chalumnae

Lepisosteus oculatus

Tetraodon nigroviridis

Takifugu rubripes

Cynoglossus semilaevis

Thalassoma bifasciatum

Oryzias latipes

Aphyosemion striatum Nothobranchius kuhntae Nothobranchius furzeri Nothobranchius pienaari Kryptolebias marmoratus Austrofundulus Iimnaeus Cyprinodon variegatus Fundulus heteroclitus Xiphophorus maculatus Poecilia latipinna Poecilia reticulata Poecilia Formosa Poecilia mexicana Oreochromis niloticus Neolamprologus brichardi Pundamilia nyererei Dicentrarchus labrax Stegastes partitus Anguilla japonica salmo salar

Ictalurus punctatus Pygocentrus nattereri Danio rerio

Carassius auratus

Cyprinus carpio

Sinocyclocheilus rhinocerous

sinocyclocheilus grahami

Homo sapiens

Coturnix japonica

Latimeria chalumnae

Lepisosteus oculatus

Tetraodon nigroviridis

Takifugu rubripes

Cynoglossus semilaevis

Thalassoma bifasciatum

Oryzias latipes

Aphyosemion striatum Nothobranchius kuhntae Nothobranchius furzeri Nothobranchius pienaari Kryptolebias marmoratus Austrofundulus limnaeus Cyprinodon variegatus Fundulus heteroclitus Xiphophorus maculatus Poecilia latipinna Poecilia reticulata Poecilia formosa Poecilia mexicana Oreochromis niloticus Neolamprologus brichardi Pundamilia nyererei Dicentrarchus labrax Stegastes partitus Anguilla japonica salmo salar Ictalurus punctatus Pygocentrus nattereri Danio rerio

Carassius auratus

Cyprinus carpio

Sinocyclocheilus rhinocerous Sinocyclocheilus grahami
--MEIISS-KLFILLTLATSSLLT--SNIFC------ADELVMSNLHSKENYD-KYSEPR --MEIIST-QKFILLTLATVAFLT--PHGAC------LDELMKSSLESREDDDDKYYEIK

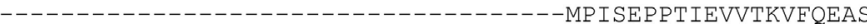
--MTP-NS-CWPVLLLLGCSVLQT--PAAQS------ADERPLSADQD-----RLDPDAT ----MLVTLFLAMLLMIAGLGKAA-VSDLQVTGKVN---DRTLGSREGRH-NMRK--ELH ----MLVTAFLAMLLMIAGIGGAA-ETDLQVNGKLN---DRTLSSREGRH-NVRK--QLR ----MLSTVFLSVLLMLGGPGGAAAAADFQVYGKSAYSDKSLPSSEEGRH-TVRR--QPL ----MSITVFLPVLLLLGALLGTV-TTNQQVLEKSVPGGKSLLSSGDGSP-TMRK--HLH ----MLTMMMLSVLLVLGGLGGAA-ASDLHVFGKS FHGDDPLES SHDSQLNMLRK--QLH ----MLTTVTLLALLMLGGLRGAA-ASDFHVFGKS I HNDETLQSSNDNRY-SIRK--LPR ----MLTTVTLLALLMLGGLGGAA-AYDFRVFGKS I HNDETLOSSNGNRY-SIRK--LPR --- MLTTVTLLALLMLGGLGGAA-AYDFRVFGKS IHNDETLQSSNGNRY-SIRK--LPR ----MLTTVTLLALLVLGGLRGAA-AYDFRVFGKS I HNDETLQSSNGNRY-SIRK--LPR ----MLTMVILLALLMLGGLGGAA-ASDFHVFGKS IHDDETLQS SNDDRH-SIRK--QPR ----MLTTVIMLALLMLGGLRGAA-ASDFHVFGKS I HDDETLQSSSSDRI-LLRK--QPR ----MLAAAILSVLLTLGGLGGAA-ASDLHIFGKSFYNDGTLRSSSDDRY-TVRK--QQS ----MFTAAVLSVLLMMGGLGGAA-ASDFHVFGKPFHNDEALRSSSDDRH-SVRK--QPR ----MLTAVILSALLMMGGLGGVA-ASDFHVFGKSLHNGEALRSS I DDRH-SVRK--QPR ----MLTAAILSALLMMGDLGGAA-ASDFHVFGKSFHNDETLRSSVDDRH-SVRK--QPR --- MLTAAI LSALLMMGGLGGAA-ASDFHVFGKSFHNDETLRS S IDDRH-SVRK--QPR ----MLTAAILSALLMMGGLGGAA-ASDFHVFGKSFHNDETLRS SVDDRH-SVRK--QPR ----MLTAAILSALLMMGGLGGAA-ASDFHVFGKSFHNDETLRSSVDDRH-SVRK--OPR ----MLVTMILSALLMLRGLGG----SDVHVFGKSVRSGKTLLSSNDGTY-SVRK--QPH $----M L V T M I L S A L L M L R G L G G----S D V H V F G K S V R S G K N L L S S N D G T Y-S V R K--Q P H$ MVVNMLVTMILSALLMLRGLGG----SDVHVFGKSVRSGKNLLSSNDGTY-SVRK--OPH ----MLTTVFLSTLLMLGGLGGAA-VSDLQVYGKS IHSDKTLLSSDDGRH-TVRK--QPH ----MLTTMMLSALLMLWGLGA----FDLQVYGKS I HSDKTLLISNDGKH-SARK--QPH ----MNRFAASLLLAAGI IGRFA-PRTVTCVG----GHGSAATFAQRAG-RLPV--YPE -----MSM-FTLVILGCLGLQGVM-ASDSRVYRMSMTNDNDGHTTSQ------RQ--HPQ ------MS-CSALSLTLVILSSLV-FQDVTTVKLPLTGNNNINTVTR------RM--FLK -----MP-CSTLSLTLGILSSLL-FQDVGAVRLPLTGDDDSNRI IN------GI--FSE -----MSY-FALLSLALGILSSFM-LSEVTALRLPLSGERDLNGFTW------GQ--FSE ---- MSY-FTLVFLALGTLSSFM-LREVTALRWPLPDDSDPDRFTW------GQ--FLE -----MSY-FTLLSLAFGILSSFM-LREVTALRLPLPDDRDPNRFTW------GQ--FPE -----MSY-FTLLFLAFGILSSFM-LREVTALRLPLPDDSDPDRFTW------GQ--FPE -----MSY-FTLLFLAFGILSSEM-LREVTVLRLPLPDDSDPDRFTW------GQ--FPE

\section{RFRP-1/GnIH-RP-1}

--GYPKGERSLNFEELKDWGPKNV-IKMSTPAVNKMP------HSFANLPLRFGRNVQDSILEEKQRS LNFEEMKDWGSKNF-MKVNTPTVNKVP----- NSVANLPLRFGRSNPQESLEERQRSLSNEQLKEWEPKAT-IKMKTPI ISKFS------ NSVINLPLRFGRAFP-

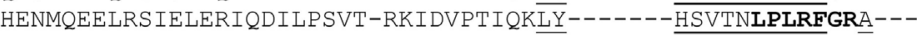
HQVKNNILRS LDLESLNI HVSPTS--KISFPTI IRLY PPTPQPP LRHINMPMRFGRN $S F H$ HQIKSNILRSLDMERINIQVSPTS-GKVSLPTIVRLY P PTLQPRHOHVNMPMRFGRDGVO QQAKAVTRRSLDLERLNMRVTPTA-SKSSLPT I IKLYPPTVNP-HIHANMPMRFGREVEP QQTKSEWRRSLDFNSFN I HSTPT--SKIRLPS I I KLYPPTVQPAYLHPNMPLRFGR QQTKRGIRRSLDLESFNIRVTPTS-SKLNLPTI I KLYPPTAKPLHMHANMPLRFGRESSA QQLTSGIRRSLDLESEKIHVTPTT-SKISLPT I IKLYPPTAK PLHMHANMPLRFGRDI -QOLMSGICRSLDLESEKIHVTPTT-SKISLPTI IKLYPPTAKPLHMHANMPLRFGRDS-QQLMSGIRRSLDLESEKIHVTPTT-SKISLPTI IKLYPPTAKPLHMHANMPLRFGRDS-QQLMSGIRRSLDLESFKI HVTPTT-SKISLPT I IKLYPPTAKPLHMHANMPLRFGRDS-OOMASGIRRSLDLESEKIHVTPAT-SKISLPTI IKLYPPTAKPLHMHANMPLRFGRES-QQMTSGIRRSLDLESFKLHVTPAT - SKISLPT I IKLYPPTAKPLHMHANMPLRFGRDS -QQMASGIRRS LDLESFKLHMTPAT - SRMSLPT I IKLYPPTAK PLHMHANMPLRFGRDS-QQVPSGIRRSLDLESFKLHMTPAT -SKMSLPTI IKLYPPTAKPLHMHANMPLRFGRDS- QQIPSGLRRSLDLESEKLHVTPAT-SRNSLPT I I KLYPPTAKPLHMHANMPLRFGRDS-QQVPSGLRRSLDLESFKLHVTPAT - SRNSLPT I I KLY PPTAKPLHMHANMPLRFGRDS - QQVPSGLRR.SLDLESEKLHVTPAT-SRNSLPTI IKLYPPTAKPLHMHANMPLRFGRDS-QQAPSGLRRSLDLESFKLHVTPAT - SRNSLPT I IKLYPPTAKPLHMHANMPLRFGRDS - QQAPSGLRRS LDLESEKLHVTPAT-SRNS LPT I I KLYPPTAKPLHMHANMPLRFGRDS-QETKNE IHRSLDLESENIRVAPTT-SKFSLPT I IREYPPTVKPLHLHANMPLRFGRQS -QETKNEIHRSLDLKSFNIHVAPTT-SKFSLPTIVRFYPPTVKPLHQHANMPLRFGRQSDP OETKNKIHRSLDLDSENI HVAPTT-SKFSLPT IVRFYPPTVKPLHOHANMPLRFGRQSHP QQAKGEIRRSLDLESFNIHVSPTT-SKISLPT I IRLYPPTAK PLHLHANMPMRFGRDSNP QQIKGEIRRSLDLESYNI HVSPTT-SKHSLPTI IRIYPPTSI PRHLHANI PMRFGRDSDP AMOESERARSLEMDDFKVOEVPDD-TMGSTPI ILKLYPPVAKPALLHANLPLRFGRSSSR --TSNEIPRS IEVDDFKINVVPTSGKVI LAPTMVRLYPPPVKTSHLHANLPLRFGRDSLS --SNEDLPRSLEMEDSTLNMAPTSSSRVNSPTILRLHPLLAKSVHTHANLPLRFGRGSAH --NSQDIPRSLEMEEFAFNVVPTS-GRASSPTILRLHPISAKPSHLHANLPLRFGREAY--NAQEIPRS LEIQDFTLNVAPTS-GGASSPTILRLHP I I PKPAHLHANLPLRFGRDAQP --NAOEIPRSLEIEDFTLNVAPTS-GRVSSPTILRLHPKITKPTHLHANLPLRFGRDTEN --NTQEIPRSLEIEDFSLNVAPTS-SRVSSPTILRLHP I IKKPTHLHANLPLRFGRDAQT --NNQEIPRSLEIEDFTLNVAPTS-SRVSSPTILRLHPI IKKPTHLHANLPLRFGRDAQT --NTQE IPRS LEMEDFTLNVAPTS-SRVSSPTILRLHPI IKKPTHLHANLPLRFGRDAQM

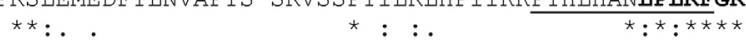

FIGURE 1 | Continued 
Homo sapiens

Coturnix japonica

Latimeria chalumnae

Lepisosteus oculatus

Tetraodon nigroviridis

Takifugu rubripes

Cynoglossus semilaevis

Thalassoma bifasciatum

Oryzias latipes

Aphyosemion striatum

Nothobranchius kuhntae

Nothobranchius furzeri

Nothobranchius pienaari

Kryptolebias marmoratus

Austrofundulus limnaeus

Cyprinodon variegatus

Fundulus heteroclitus

Xiphophorus maculatus

Poecilia latipinna

Poecilia reticulata

Poecilia formosa

Poecilia mexicana

oreochromis niloticus

Neolamprologus brichardi

Pundamilia nyererei

Dicentrarchus Iabrax

Stegastes partitus

Anguilla japonica

Salmo salar

Ictalurus punctatus

Pygocentrus nattereri

Danio rerio

Carassius auratus

Cyprinus carpio

Sinocyclocheilus rhinocerous

Sinocyclocheilus grahami

Homo sapiens

Coturnix japonica

Latimeria chalumnae

Lepisosteus oculatus

Tetraodon nigroviridis

Takifugu rubripes

Cynoglossus semilaevis

Thalassoma bifasciatum

Oryzias latipes

Aphyosemion striatum

Nothobranchius kuhntae

Nothobranchius furzeri

Nothobranchius pienaari

Kryptolebias marmoratus

Austrofundulus limnaeus

Cyprinodon variegatus

Fundulus heteroclitus

Xiphophorus maculatus

Poecilia latipinna

Poecilia reticulata

Poecilia formosa

Poecilia mexicana

oreochromis niloticus

Neolamprologus brichardi

Pundamilia nyererei

Dicentrarchus labrax

Stegastes partitus

Anguilla japonica

Salmo salar

Ictalurus punctatus

Pygocentrus nattereri

Danio rerio

Carassius auratus

Cyprinus carpio

Sinocyclocheilus rhinocerous

Sinocyclocheilus grahami

\section{RFRP-2/GnIH}

RFRP-3

--EERSAGATANLPLRSGRNMEVSLV--------RRV-------PNLPORFGRTTTAKS--EERS IKPSAYLPLRFGRAFGESLS-------RRA -------PNLSNRSGRSPLARS--DGRLSQSLANLPLRLGRALENRIP-------MAI-------PNLPQRFGRSPLVKS -

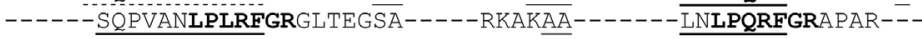
G-DDHNPNSAPNMPQRFGRSWKK----IQLCEGCYEAHR--I----LKHRVKHARNGQR$\bar{G}-\overline{G D H V P N L N P K M P Q R F} G R S W K V----I R L C E D C S K V Q G--V----L K H Q V R Y G R N G Q S-$ E-DDQSHN-TPNMPQRFGRAWTF----NRVCVKCRGDAD--Q-------VLPGTSLYWSS-DINGPNSTPNMPQRFGRGWEM----VQRCAECSRVQE--RGHGVLPQRFGRSSLNWR$\bar{S}$-DDRVSNSS PNMPQRFGRAWEV----LRMCGGCRSVRE--A PS PVLPQRFGRNTPHWGS-DDRAPNSSPNMPQRFGRSWEL----LQMCAECRDVRE--APSPVLPQRFGRNAPYWNS-DDRAPNSRPNMPQRFGRSWEL----LQMCGECRDIRE--APSPVLPQRFGRNAPYWSS-DDRAPNSRPNMPQRFGRSWEL----LQMCGECRDIRE--APSPVLPQRFGRNAPYWSS-DDRAPNSSPNMPQRFGRSWEL----LQMCGECRDIRE--APSPVLPORFGRNAPYWSS-DDRAPNSSPNMPQRFGRSWEV----LRMCGECRDIRE--AQSPVLPQRFGRNVPYWS -

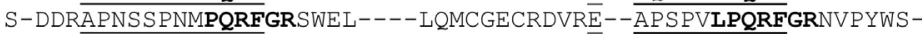
N-DERVPNSSPNMPQRFGRSWEL----IQMCGECREVRD--SPSPVLPQRFGRNIPYWSN-DERVPNSSPNMPQRFGRSWGL----IRLCGECRGVRD-- APSPVLPQRFGRNAPYWSS-DERVPNSSPNMPQRFGRSWEL----VEMCGECREARD--APSPVLPQRFGRNAPYWS N-DERVPNSSPNMPQRFGRSWEL---IQMCGECREARD-- $\overline{A P S P V L P Q R F G R D A P Y W S ~-~}$

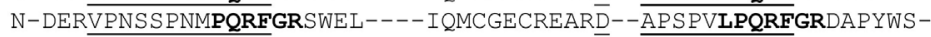
N-DERVPNSSPNMPQREGRSWEL----IQMCGECREARD--APSPVLPQRFGRDAPYWSN-DERVPNSSPNMPQRFGRSWEL----IQMCGECREARD--APSPVLPQRFGRDAPYWS --DERTPNSSPNLPQRFGRSWEA----IRVCAECPSVRR-- $\overline{A P N Q L L S Q R F E R N S P Y W K-~}$ S-DEKTPNSSPNLPQRFGRSWEA----IRVCAECPS IRR--APNQVLSQRFERNSPYWKS-DERTPNSSPNLPQRFGRSWVA----IRVCAECPS IRR--APNQVLSQRFERNSPYWKG-DDR SPNSTPNMPQRFGRSWEV----FQMCAECPGVQE--PPK--SPQGLRRTSLYWSR-DGRAPS-SPNKPQRFGRSSKL----IQMCADCPDVRE--APNPVLPQRFGRNSPYWS A-AAQMLQFPLSLTRRFGRSPETSPIALPCHQCARIGGVA SP SATLPQRFGRTNRFDSR D-DTHSPKTTLNLPORFGRAOGSGETEPMSCIECPHVGT--LPSATLPORFGRNEFNRRY --MLRMPKSS INLPQRFGR SENTKPTSGMQCTMCRRSEN--PPSATLPQRFGKRNLLVGD --IERTPKSSINLPQRFGRSQEGDLTSGQQCNECRRAES--PPSATLPQRFGRRN IFVED GTGDRAPKSTINLPORFGR--------SCTMCARSGT--GPSATLPORFGRRN IFALD

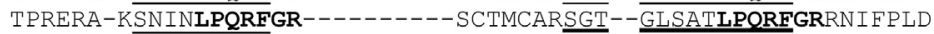
SARDRASK STINLPQRFGR---------SCTMCERSGT--GPSATLPQRFGRGNIFTSD SARDRASKSTINLPQRFGR---------SCTKCERSGP--GPSATLPQRFGRGNMFTLD

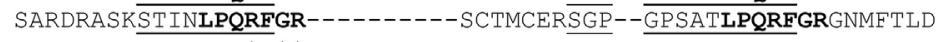

\section{GnIH-RP-2}

VCRMLSDLCQGSMHSPCANDLFYSMTCQHQEIQNP-------DQKQSRRLLFKKIDDAEL SIOSLLNLPQREGKS-----VPISLSQGVQE-SEP-------GM-------------FMQPLANLPQRFGRSPFYDKFIQSVANLPQRFGRS PSVSNYPHSTVAFPVQFERYQQTN-

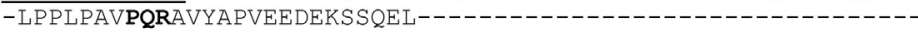
FISTLLNA--------------------QL----L---KSALHW---------------LIRTLVNA------------------QQL----L---KTGLHW--------------LINSLAVE------------------QF----F---NTDLHWAEDFDLTANAEE--LE LLKTLIGD-------------------RL----M---IR----PHEQDFTAS SEEMEMO FLNTLANE------------------QL----I---NPELRWNKDIDLPI S SEEEEME LLRTLASE-----------------OL----L---NTGLHWSEDLDFKS S - SEEDAD LLRTLASE------------------QL----L---NTGVRWSEDFDFTSS-SEEDAD LLRTLASE------------------QQL----L---NTGVRWSEDFDFTSS-SEEDAD LLRTLASE-----------------QL----L---NTGVRWSEDFDFTSS - SEEDAD LLRTLTSE-----------------QL----L---NTGLHWTEDFDFKRS - SEEDEE LLRTLASE------------------HL----L---NTGLSWVEDLGFKRS - SEEDEM LLRTLASD------------------DL----V---DTGLHWTQDFDFKTSSSEEDVE LLRTLASE-------------------HL----L---DTSLQWAEDFDFKTS - SEEDVE

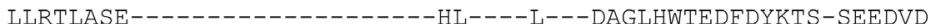
LLRTLASE------------------HL----L---DAGLHWTEDFDYKTS-SEEDVD LLRTLASE------------------HL----L---DAGLHWTEDFDYKTS-SEEDVD LLRTLASE-----------------HL----L---DAGLHWTEDFDYKTS-SEEDVD LLRTLASE-------------------HL----L---DAGLHWTEDFDYKTS-SEEDVD LLRTVASE------------------QL----L---NTGLHWAENFDSTTTSDEET $-\mathrm{E}$ LLRTVASK------------------QL----L---NTGLHWAENFDSTTTSDEET-E LLRTVAIE------------------QL----L---NTGLHWAENFDSTTTSDEET-E LLRTLANA------------------EL----L---NTGLHWAEDI DFTTS SEEMQ-M

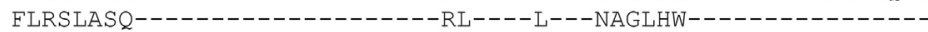
PARTLAMF-----------------ARGIAAQ---LQRRSQARGLSFVDDVREEDIL PFRAMAFF------------------SRRSEPV---PNGNIRQQDYNYYDFGSEEEET SFRAGAVE-------------------VHTCKM------PSLRTPDHDYMTEVVEKE-PFRALAIF-------------------TRTLESP----EPRDRTEDYDYMLETIQED-PLRALALY-----------------TRTPESP---SFPKERTQVHDYMFETVEDS-PFRALTLY-------------------KRTPESP----FPKERTQVHDYMLETVEDS-PFRASTLY------------------TRTPESP----EPRERTQVHDYMFET-EDS-PFRALTLY------------------TRTPESP----EPKERTQVHDYMFETVEDS-PFRALTLY ------------------- TRKPESP----EP ------------------

FIGURE 1 | Continued 


\begin{tabular}{|c|c|}
\hline Homo sapiens & KQEK-- \\
\hline Coturnix japonica & --- \\
\hline Latimeria chalumnae & --- \\
\hline Lepisosteus oculatus & --- \\
\hline Tetraodon nigroviridis & ------- \\
\hline akifugu rubripes & 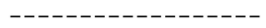 \\
\hline noglossus semilaevis & MERTSFKG -------- \\
\hline halassoma bifasciatum & $--\mathrm{E}---------------$ \\
\hline Oryzias latipes & GKDIYNMK---------- \\
\hline Aphyosemion striatum & MEDKSFKG $--\ldots-n-\ldots$ \\
\hline Nothobranchius kuhntae & MEEKTFKG---------- \\
\hline Nothobranchius furzeri & MEVKTFKG---------- \\
\hline Nothobranchius pienaari & MEEKTFKG--------- \\
\hline Kryptolebias marmoratus & VEEKNL--------- \\
\hline Austrofundulus Iimnaeus & EEKTEKE-------- \\
\hline Cyprinodon variegatus & TEEKAFKG------ \\
\hline Fundulus heteroclitus & TEEKSFKG------ \\
\hline Xiphophorus maculatus & TDEKTFKG------ \\
\hline Poecilia latipinna & TNEQTFKG------- \\
\hline Poecilia reticulata & TDKKTFKG------ \\
\hline Poecilia formosa & TDEKTFKG------ \\
\hline Poecilia mexicana & TDEKTFKG------- \\
\hline Oreochromis niloticus & LEEKKSKE--------- \\
\hline Neolamprologus brichardi & LEEKKSK----------- \\
\hline Pundamilia nyererei & LEEKKSK----------- \\
\hline Dicentrarchus labrax & -QEKTFNG---------- \\
\hline Stegastes partitus & ------------------- \\
\hline Anguilla japonica & NIPKDIEASSSPASD--- \\
\hline Salmo salar & -REKTLKSSTLDLLLWNS \\
\hline Ictalurus punctatus & --DKALKSKTYIDLEI-- \\
\hline Pygocentrus nattereri & --DKALKSKKYID----- \\
\hline Danio rerio & --EETVKNTDYTALD--- \\
\hline Carassius auratus & -VEETVKNKDYTVLD--- \\
\hline Cyprinus carpio & --EETVKRTDYTALD--- \\
\hline Sinocyclocheilus rhinocerous & --EETVKRTDYTALD--- \\
\hline Sinocyclocheilus grahami & ------------------ \\
\hline
\end{tabular}

FIGURE 1 | The alignment of gonadotropin-inhibitory hormone $(\mathrm{Gn} \mid \mathrm{H})$ precursor polypeptides of human, Japanese quail, coelacanth, spotted gar, and various teleost fish species. The GnlH precursor polypeptide sequences were aligned by using EMBL-EBI Clustal Omega Multiple Sequence Alignment software. The characteristic amino acid sequence of the GnlH peptide, Leu (L), Pro (P), Leu (L) or Gln (Q), Arg (R), Phe (F) with Gly (G) as an amidation signal followed by Arg (R) or Lys $(K)$ as an endoproteolytic basic amino acid at the C-termini are shown in bold. Identified mature GnlH peptide sequences in human (Homo sapiens), Japanese quail (Coturnix japonica), and goldfish (Carassius auratus) are underlined with thick lines. Possible mature GnlH peptide sequences that may be cleaved after the first N-terminal basic amino acids ( $\mathrm{R}$ or $\mathrm{K}$ ) are underlined with thin lines. Possible mature GnlH-like peptide sequences that may be cleaved after the first N-terminal basic amino acids (R or K), which have C-terminal-LPLRSamide (human), -LSNRSamide (Japanese quail), and LPLRLamide sequences (Latimeria chalumnae, coelacanth) are underlined with broken lines. Accession numbers of GnlH precursor polypeptide sequences in US National Center for Biotechnology Information database are Homo sapiens (NP_071433.3), Coturnix japonica (XP_015709159.1), Latimeria chalumnae (XP_005993154.1), Lepisosteus oculatus (XP_015213317.1), Tetraodon nigroviridis (BAF34880.1), Takifugu rubripes (NP_001092115.1), Cynoglossus semilaevis (AMB48604.1), Thalassoma bifasciatum (ANV28067.1), Oryzias latipes (XP_004073896.1), Aphyosemion striatum (SBP35361.1), Nothobranchius kuhntae (SBQ91527.1), Nothobranchius furzeri (XP_015811406.1), Nothobranchius pienaari (SBR89569.1), Kryptolebias marmoratus (XP_017278134.1), Austrofundulus limnaeus (XP_013866639.1), Cyprinodon variegatus (XP_015229614.1), Fundulus heteroclitus (XP_012729657.1), Xiphophorus maculatus (XP_005802819.1), Poecilia latipinna (XP_014884496.1), Poecilia reticulate (XP_008419875.1), Poecilia formosa (XP_007562706.1), Poecilia mexicana (XP_014852162.1), Oreochromis niloticus (NP_001298256.1), Neolamprologus brichardi (XP_006788138.1), Pundamilia nyererei (XP_013765199.1), Dicentrarchus labrax (CEK03537.1), Stegastes partitus (XP_008290012.1), Anguilla japonica (BAV18007.1), Salmo salar (XP_013998456.1), Ictalurus punctatus (XP_017336524.1), Pygocentrus nattereri (XP_017549097.1), Danio rerio (NP_001076418.1), Carassius auratus (BAC06473.1), Cyprinus carpio (AML83913.1), Sinocyclocheilus rhinocerous (XP_016370559.1), and Sinocyclocheilus grahami (XP_016150344.1). Refer to Table 1 for the common names, class, order, and family of these species. *Indicates positions which have a single, fully conserved amino acid residue, and symbols : and . indicate conservation between groups of strongly (:) and weakly (.) similar amino acid properties, respectively.

they align to human RFRP-1/quail GnIH-RP-1, human RFRP-2/ quail GnIH, and human RFRP-3 (Figure 1). The C-terminal sequence of the LPXRFamide-like peptides that aligns to human RFRP-1/quail GnIH-RP-1 is-MPLRFamide in Labriformes, Beloniformes, Cyprinodontiformes, and Cichliformes (Figure 1; Table 1). The C-terminal-LPLRFamide peptides align to human RFRP-1/quail GnIH-RP-1 in Anguilliformes, Salmoniformes, Siluriformes, Characiformes, and Cypriniformes (Figure 1; Table 1). The C-terminal sequence of the LPXRFamide-like peptides that aligns to human RFRP-2/quail GnIH is-MPQRFamide in Tetraodontiformes, Pleuronectiformes, Labriformes, Beloniformes, Cyprinodontiformes, and some Perciformes (Figure 1; Table 1). The C-terminal LPQRFamide peptides align to human RFRP-2/quail GnIH in Cichliformes, Salmoniformes, Siluriformes, Characiformes, and Cypriniformes (Figure 1; Table 1). The C-terminal LPQRFamide peptides align to human RFRP-3 in Labriformes, Beloniformes, Cyprinodontiformes, Anguilliformes, Salmoniformes, Siluriformes, Characiformes, Cypriniformes, and some Perciformes (Figure 1; Table 1).

In summary, most of the teleost $\mathrm{GnIH}$ precursor polypeptides encode three LPXRFamide or LPXRFamide-like peptides, which align to human RFRP-1/quail GnIH-RP-1, human RFRP-2/quail $\mathrm{GnIH}$, and human RFRP-3. The C-terminal sequences are mostly conserved in the peptide sequences that align to human RFRP-1/ quail GnIH-RP-1, followed by those that align to human RFRP-2/ quail GnIH. However, the C-terminal sequence of the peptides 
TABLE 1 | Scientific name, common name, class, order, and family of the species analyzed.

\begin{tabular}{|c|c|c|c|c|}
\hline Scientific name & Common name & Class & Order & Family \\
\hline Homo sapiens & Human & Mammalia & Primates & Hominidae \\
\hline Coturnix japonica & Japanese quail & Aves & Galliformes & Phasianidae \\
\hline Latimeria chalumnae & Coelacanth & Sarcopterygii & Coelacanthiformes & Coelacanthidae \\
\hline Lepisosteus oculatus & Spotted gar & Actinopterygii & Semionotiformes & Lepisosteidae \\
\hline Tetraodon nigroviridis & Spotted green pufferfish & Actinopterygii & Tetraodontiformes & Tetraodontidae \\
\hline Takifugu rubripes & Torafugu & Actinopterygii & Tetraodontiformes & Tetraodontidae \\
\hline Cynoglossus semilaevis & Tongue sole & Actinopterygii & Pleuronectiformes & Cynoglossidae \\
\hline Thalassoma bifasciatum & Bluehead wrasse & Actinopterygii & Labriformes & Labridae \\
\hline Oryzias latipes & Japanese medaka & Actinopterygii & Beloniformes & Adrianichthyidae \\
\hline Aphyosemion striatum & Red-striped killifish & Actinopterygii & Cyprinodontiformes & Nothobranchiidae \\
\hline Nothobranchius kuhntae & Beira killifish & Actinopterygii & Cyprinodontiformes & Nothobranchiidae \\
\hline Nothobranchius furzeri & Turquoise killifish & Actinopterygii & Cyprinodontiformes & Nothobranchiidae \\
\hline Nothobranchius pienaari & Black rachovii & Actinopterygii & Cyprinodontiformes & Nothobranchiidae \\
\hline Kryptolebias marmoratus & Mangrove rivulus & Actinopterygii & Cyprinodontiformes & Rivulidae \\
\hline Austrofundulus limnaeus & Annual killifish & Actinopterygii & Cyprinodontiformes & Rivulidae \\
\hline Cyprinodon variegatus & Sheepshead minnow & Actinopterygii & Cyprinodontiformes & Cyprinodontidae \\
\hline Fundulus heteroclitus & Mummichog & Actinopterygii & Cyprinodontiformes & Fundulidae \\
\hline Xiphophorus maculatus & Southern platyfish & Actinopterygii & Cyprinodontiformes & Poeciliidae \\
\hline Poecilia latipinna & Sailfin molly & Actinopterygii & Cyprinodontiformes & Poeciliidae \\
\hline Poecilia reticulata & Guppy & Actinopterygii & Cyprinodontiformes & Poeciliidae \\
\hline Poecilia formosa & Amazon molly & Actinopterygii & Cyprinodontiformes & Poeciliidae \\
\hline Poecilia mexicana & Shortfin molly & Actinopterygii & Cyprinodontiformes & Poeciliidae \\
\hline Oreochromis niloticus & Nile tilapia & Actinopterygii & Cichliformes & Cichlidae \\
\hline Neolamprologus brichardi & Princess cichlid & Actinopterygii & Cichliformes & Cichlidae \\
\hline Pundamilia nyererei & Lake Victoria cichlid & Actinopterygii & Cichliformes & Cichlidae \\
\hline Dicentrarchus labrax & European sea bass & Actinopterygii & Perciformes & Moronidae \\
\hline Stegastes partitus & Bicolor damselfish & Actinopterygii & Perciformes & Pomacentridae \\
\hline Anguilla japonica & Japanese eel & Actinopterygii & Anguilliformes & Anguillidae \\
\hline Salmo salar & Atlantic salmon & Actinopterygii & Salmoniformes & Salmonidae \\
\hline Ictalurus punctatus & Channel catfish & Actinopterygii & Siluriformes & Ictaluridae \\
\hline Pygocentrus nattereri & Red-bellied piranha & Actinopterygii & Characiformes & Serrasalmidae \\
\hline Danio rerio & Zebrafish & Actinopterygii & Cypriniformes & Cyprinidae \\
\hline Carassius auratus & Goldfish & Actinopterygii & Cypriniformes & Cyprinidae \\
\hline Cyprinus carpio & Common carp & Actinopterygii & Cypriniformes & Cyprinidae \\
\hline Sinocyclocheilus rhinocerous & horned golden-line barbel & Actinopterygii & Cypriniformes & Cyprinidae \\
\hline Sinocyclocheilus grahami & golden-line barbel & Actinopterygii & Cypriniformes & Cyprinidae \\
\hline
\end{tabular}

Scientific name is indicated in the common name section if there is no common name. Classification is based on NCBI Taxonomy Browser besides Dicentrarchus labrax and

Stegastes partitus, which are based on World Register of Marine Species.

that align to human RFRP-3 include all LPQRFamide in teleost fish precursor polypeptides that encode the third LPXRFamidelike or LPXRFamide peptide. The mature teleost fish GnIH peptide structure was only identified in goldfish by immunoaffinity chromatography and mass spectrometry (8), which aligns to human RFRP-3 (Figure 1). The possible N-terminal sequences of teleost fish LPXRFamide or LPXRFamide-like peptides are also well conserved within fish if the peptides were cleaved after the first basic amino acid (Arg or Lys). These results suggest that three or two LPXRFamide or LPXRFamide-like peptides exist in teleost fish. The elucidation of the physiological roles of different endogenous LPXRFamide or LPXRFamide-like peptides should require further investigation in future studies.

\section{DISTRIBUTION OF GnIH AND GnIH RECEPTORS (GnIH-Rs) IN FISH}

The presence and distribution of GnIH orthologs and their receptors have been explored mainly in the brain but also in peripheral tissues of different vertebrate species by using PCR, immunoassays, immunohistochemistry, and/or in situ hybridization. Although the location of $\mathrm{GnIH}$ varies among species and the method used for the detection, some features, such as the presence of a periventricular preoptic/hypothalamic $\mathrm{GnIH}$ cell population and a profuse brain $\mathrm{GnIH}$ innervation, are recurring among studies (25). In mammals, several studies have been performed in rodents, ovine, and primates (including humans), with GnIH cells being identified mainly in the hypothalamus (paraventricular nucleus, dorsomedial nucleus, mediobasal, and ventromedial hypothalamus), as well as in the olfactory bulbs, hippocampus, medulla oblongata, and/or spinal cord, but $\mathrm{GnIH}$ is also produced in the eye, testis, and ovary $(3,6,22,26,27)$. The paraventricular nucleus of the avian and reptile hypothalamus also contains $\mathrm{GnIH}$ cells $(1,28-34)$, in addition the nucleus accumbens and the upper medulla of the Japanese grass lizard was also identified as containing $\mathrm{GnIH}$ cells (35). In amphibians, studies carried out in the bullfrog, the European green frog and newt have identified GnIH neurons in the mediobasal telencephalon (medial septum, nucleus of the diagonal band of Broca, 
and the medial and dorsal pallium) and the diencephalon (anterior preoptic area, suprachiasmatic nucleus, ventral, and dorsal hypothalamic nuclei) (36-39). The pattern of GnIH innervation in the brain of tetrapods is highly consistent with the presence of GnIH-Rs $(25,40)$. In most tetrapod species studied to date, $\mathrm{GnIH}$ neurons project to the median eminence to control anterior pituitary function, and $\mathrm{GnIH}$-Rs are present in the gonadotropes $(10,23,25,40)$. GnIH neurons also project to GnRH-1 and GnRH-2 neurons, which also express GnIH-Rs, at least in birds [GnRH-1 and GnRH-2 neurons; (10, 33, 40)] and hamsters [only GnRH-1 neurons; (7)]. The presence of a profuse GnIH innervation and/or GnIH-Rs outside the hypothalamus and pituitary, from the telencephalon to the rhombencephalon, suggest that $\mathrm{GnIH}$ could be involved in functions other than reproduction and could exert pleiotropic actions in vertebrates.

Despite teleost fishes constituting the most abundant group of vertebrates, studies reporting the distribution of $\mathrm{GnIH}$ cells and their projections are scarce and have been addressed in only a few species (Figure 2). In addition, most of these studies have used heterologous antibodies and, only recently, specific antibodies to fish $\mathrm{GnIH}$ orthologous peptides have been developed in sea bass and tilapia $(41,42)$. In goldfish, developing Indian major carp Labeo rohita, cichlid fish Cichlasoma dimerus, and sea bass, immunohistochemistry has revealed the presence of $\mathrm{GnIH}$ immunoreactive (ir) cells in the terminal nerve/olfactory bulbs $(8,41,43,44)$. However, no labeled cells were detected in the terminal nerve of goldfish by using in situ hybridization, which could reflect that GnIH transcripts exhibit low levels or that the antibody used is cross-reacting with another unknown peptide(s) present in this region (8). There are reports showing that NPFF, a sister gene of $\mathrm{GnIH}$, is expressed in the terminal nerve cells of dwarf gourami, Colisa lalia, and medaka, Oryzias latipes $(45,46)$. In this sense, the use of a more sensitive technique as laser capture microdissection followed by quantitative real time PCR evidenced that GnIH transcripts can also be detected in terminal nerve GnIH-ir cells of sea bass (41), indicating that immunostained cells in this area represent true GnIH-synthesizing cells, at least in this species. Recently, Corchuelo et al. (47) characterized $\mathrm{GnIH}$ in the olfacto-retinal system of zebrafish (Danio rerio) by using RT-PCR and $\mathrm{qPCR}$, detecting gnih expression in the olfactory epithelium, olfactory bulbs and retina of zebrafish during different stages of oocyte maturation. Moreover, these authors showed inverse expression of gnih and gnrh 3 in the olfactory bulbs (47). The presence of $\mathrm{GnIH}$-ir cells in the ventral telencenphalon ( Vl) was also reported in the sea bass brain (41). In agreement with these observations, conventional PCR showed important LPXRFamide mRNA levels in the olfactory bulbs/ telencephalon of sea bass (41). A conspicuous population of GnIH-ir neurons was consistently detected in the periventricular region of the preoptic area/hypothalamus of all vertebrate groups analyzed, including fish. In the lamprey (Petromyzon marinus), the presence of a GnIH cell population has been reported in the hypothalamic bed nucleus of the tract of the postoptic commissure (12). GnIH cells were located in the posterior periventricular nucleus (NPPv) of the caudal preoptic area of goldfish, sockeye salmon, Indian major carp, Cichlasoma dimerus, sea bass, and tilapia $(8,15,41-44)$, in the ventral zone of the periventricular hypothalamus of zebrafish (48), as well as in the periventricular preoptic nucleus (NPP) and magnocellular preoptic nucleus (NPOm) of Indian major carp (43). Moreover, GnIH-ir perikarya were found in the dorsal mesencephalic tegmentum (close to the nucleus of the medial longitudinal fascicle), as well as in the rhombencephalon of sea bass (secondary gustatory nucleus) and adult Indian major carp (nucleus reticularis, octaval nucleus, and motor nucleus of the vagal nerve) $(41,43)$. These results are consistent with the important GnIH mRNA levels detected in the midbrain-hindbrain of sea bass by conventional PCR, and laser capture microdissection of caudal $\mathrm{GnIH}$-ir cells followed by qPCR (41), but similar mesencephalic and rhombencephalic cell masses have not been reported in other teleost species.

A common feature between species analyzed is the profuse innervation of $\mathrm{GnIH}$ cells within the fish brain, which is particularly evident in the preoptic area, hypothalamus, optic tectum, semicircular torus, and caudal midbrain tegmentum but also has been reported in the olfactory bulbs, ventral/dorsal telencephalon, habenula, pineal, ventral thalamus, vascular sac, pretectum, rostral midbrain tegmentum, posterior tuberculum, reticular formation, and facial-vagal sensory lobe (8, 15, 41-44). The ventral telencephalon, the preoptic area, and the mediobasal hypothalamus of fish have a known presence of GnRH-1 cells, the latter also containing kisspeptin (Kiss2) neurons $(49,50)$. The presence of $\mathrm{GnIH}$-ir projections and $\mathrm{GnIH}$-Rs have been reported in GnRH-1 cells of mammals $(6,7,23,51)$ and birds $(33,34,52)$, as well as on kisspeptin neurons of mammals (53). In zebrafish, LPXRFa fibers interact with GnRH-3 soma from the preoptic area (48) but neither LPXRFa-ir fibers nor LPXRFa-R were found closely associated or coexpressed with GnRH-1, GnRH-3, or Kiss2 neurons in tilapia (42). Whether the association of GnIH with GnRH and kisspeptin neurons exhibits seasonal plasticity in fish or is dependent on the physiological conditions of the animals, as reported in birds (54) should be clarified in future research. But at least in sea bass, diencephalic GnIH expression exhibits marked seasonal variations, with higher transcript levels in the resting season related to the reproductive season (55).

Gonadotropin-inhibitory hormone-ir fibers coursing through the ventral hypothalamus also innervate the fish pituitary, as has been observed in goldfish, sockeye salmon, developing Indian major carp, sea bass, and tilapia (8, 15, 41-43). However, no $\mathrm{GnIH}$-ir fibers or GnIH-ir cells were detected in the pituitary of the cichlid fish Cichlasoma dimerus or adult Indian major carp (43). The NPPv of goldfish and sea bass contains hypophysiotropic neurons $(41,56)$ that could represent the source of $\mathrm{GnIH}$ projections reaching the pituitary. In sea bass, DiI tract-tracing and immunohistochemical studies revealed that $\mathrm{GnIH}$ cells of the ventral telencephalon could also be the origin of the pituitary $\mathrm{GnIH}$ innervation (41). GnIH-ir fibers present in the pituitary of sea bass and tilapia were observed in close proximity of FSH and LH cells of the proximal pars distalis, supporting the neuroendocrine effects of $\mathrm{GnIH}$ on gonadotropin synthesis and/or secretion reported in both species $(41,42)$. Furthermore, most LH cells from the ventral part of the proximal pars distalis were immunolabeled with the tilapia LPXRFa antibody, suggesting that $\mathrm{GnIH}$ can also exert autocrine/paracrine effects in the pituitary of this species (42). The sea bass also exhibited GnIH-ir terminals 
adjacent to $\mathrm{GH}$ cells (41), whereas tilapia displayed positive $\mathrm{GnIH}$ fibers innervating POMC cells from the rostral pars distalis and $\alpha-\mathrm{MSH}$ and somatolactin cells of the pars intermedia (42).

The actions of $\mathrm{GnIH}$ are elicited through its binding with GnIH-Rs belonging to the seven transmembrane $G$ protein-coupled receptor family. From the two potential GnIH-Rs identified in vertebrates (GPR147 and GPR74), GPR147 appears to represent the functional receptor for GnIH (25). Less abundant are the studies concerning the identification and distribution of GnIH-Rs in fish. These studies have identified one GnIH-R
Lamprey

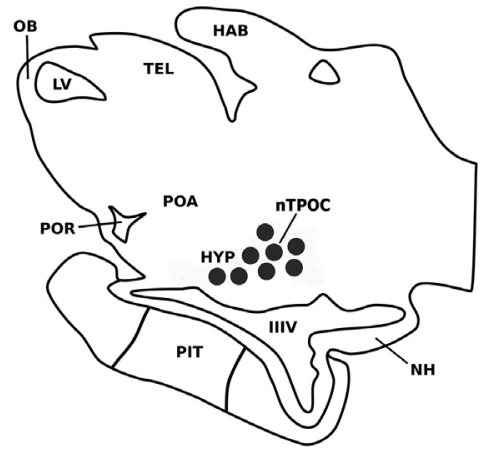

Sockeye salmon

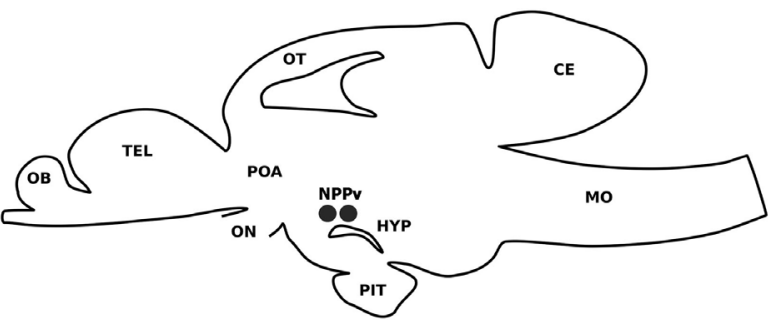

European sea bass

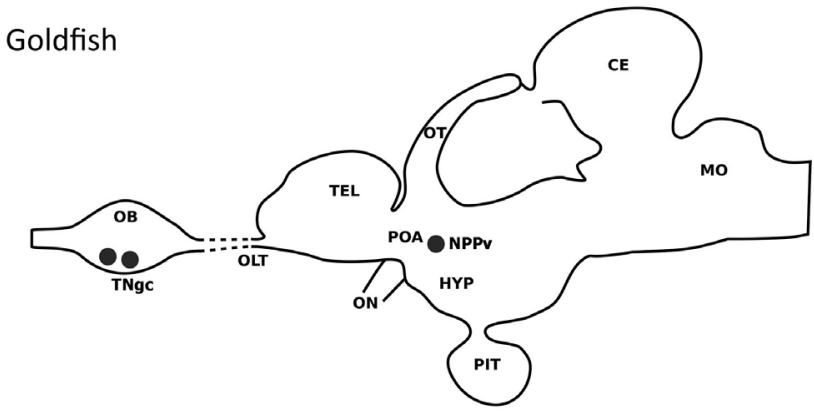

Indian Major Carp

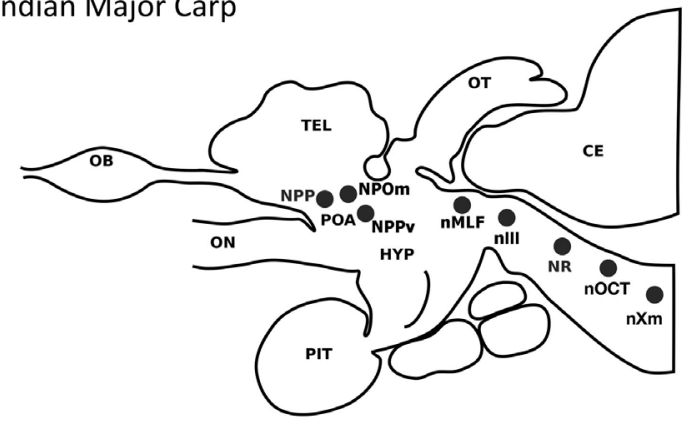

Cichlasoma dimerus

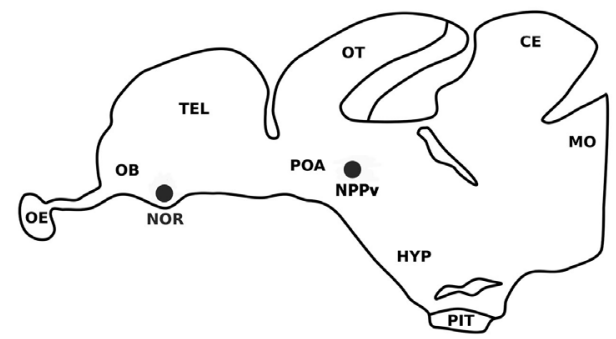

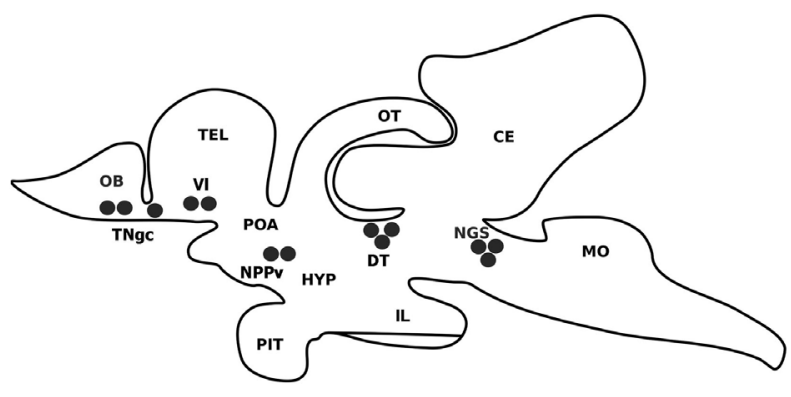

Tilapia

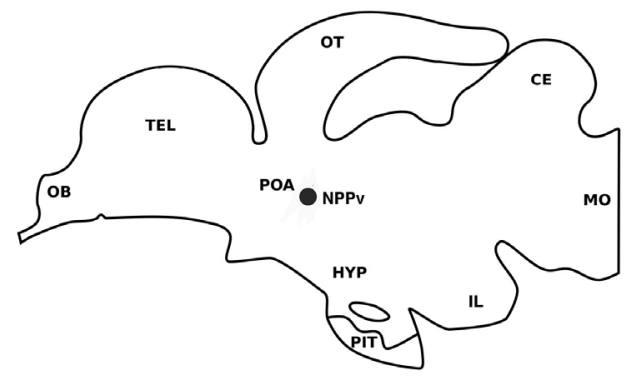




\section{FIGURE 2 | Continued}

Comparison of the localization of gonadotropin-inhibitory hormone (GnIH) cells in a jawless fish (lamprey) and various teleost species (European sea bass, sockeye salmon, Indian major carp, goldfish, cichlid Cichlasoma dimerus, tilapia). GnlH cell populations are represented by black circles. In the lamprey, cells have been reported in the hypothalamic bed nucleus of the tract of the postoptic commissure. In teleosts, the presence of a prominent population of GnlH cells in the posterior periventricular nucleus of the caudal preoptic area is a common feature. GnlH cells have also been reported in the terminal nerve/olfactory bulbs of some teleost species (European sea bass, Cichlasoma dimerus, and developing Indian major carp). GnlH cells were also detected in the terminal nerve of the olfactory bulb of goldfish by immunohistochemistry, but not by in situ hybridization. Additional GnlH cell masses were detected in the ventral telencephalon of the European sea bass, as well as in the dorsal tegmentum and rhombencephalon of the European sea bass and adult Indian major carp. Abbreviations: CE, cerebellum; DT, dorsal tegmentum; HAB, habenula; HYP, hypothalamus; IIIV, third ventricle; IL, inferior lobe of the hypothalamus; LV, lateral ventricle; MO, medulla oblongata; NGS, secondary gustatory nucleus; NH, neurohypophysis; nlll, oculomotor nucleus; nMLF, nucleus of the median longitudinal fascicle; nOCT, octaval nucleus; NOR, nucleus olfacto-retinalis; NPOm, magnocellular preoptic nucleus; NPP, periventricular preoptic nucleus; NPPv, posterior periventricular nucleus; NR, nucleus reticularis; nTPOC, nucleus of the tract of the postoptic commissure; nXm, motor nucleus of the vagal nerve; OB, olfactory bulb; OE, olfactory epithelium; OLT, olfactory tract; ON, optic nerve; OT, optic tectum; PIT, pituitary; POA, preoptic area; POR, preoptic recess; TEL, telencephalon; TNgc, terminal nerve ganglion cells; $\mathrm{VI}$, lateral nucleus of the ventral telencephalon.

(GPR147 type) in several species such as the torafugu (31), grass puffer, Takifugu niphobles (25), tilapia (17), and sea bass (41), and one GPR147/GnIH receptor was also predicted from gene databases of the coelacanth L. chalumnae, spotted gar, Mexican tetra, Astyanax mexicanus, rainbow trout, Oncorhynchus mykiss and bicolor damselfish, Stegastes partitus (25). In tilapia, the binding of tiGnIH to GPR147/GnIH-R activates cAMP/PKA (CRE) and $\mathrm{Ca}^{2+} / \mathrm{PKC}$ (SRE) pathways (17). Interestingly, three different GPR147/GnIH-Rs have been isolated and characterized in two cypriniform species including the zebrafish (16) and the goldfish (57). In zebrafish, receptor activation studies using a heterologous cell-based system, revealed that all three zebrafish LPXRFa peptides activate GPR147/GnIH-R2 and GPR147/ GnIH-R3 via the PKA/cAMP pathway (48). However, no dose response of the SRE pathway $\left(\mathrm{PKC} / \mathrm{Ca}^{2+}\right)$ was detected by any of the three LPXRFa peptides with any of the three GPR147/ GnIH-Rs in this species (48). In addition, two different NPFFR receptors from GPR74 subtype were identified in the torafugu, zebrafish and tilapia $(16,17,31)$. The effect of medaka GnIH and NPFF on the intracellular cAMP/PKA pathway was investigated in HEK293-T cells transfected with GPR147 or GPR74 subtypes by CRE-luciferase assays (46). GnIH dose-dependently inhibited CRE-luciferase activity stimulated by forskolin in HEK-293-T cells expressing GPR147 at low concentrations from $10^{-13}$ to $10^{-9} \mathrm{M}$, but this inhibitory effect diminished dosedependently at higher concentrations from $10^{-9}$ to $10^{-5} \mathrm{M}$. A similar effect of NPFF was observed in HEK293-T cells expressing GPR74-1 or GPR74-2. When GnIH or NPFF was applied without forskolin, a dose-dependent increase in CRE-luciferase activity was observed at concentrations of $10^{-8} \mathrm{M}$ and higher. It is likely that switch of coupling of GPR147/GPR74 from $G_{\mathrm{i}}$ to $G_{\mathrm{s}}$ proteins from lower to higher concentrations of $\mathrm{GnIH}$ or NPFF may happen in fish (46).

The presence of GnIH-Rs has been identified in central and peripheral tissues of zebrafish, grass puffer, goldfish, and tilapia by RT-PCR $(16,17,58-60)$. In zebrafish, the three GnIH receptor genes are expressed in the brain, eye, testis, kidney, spleen, heart, and gill, two of them (gnih-r1 and gnih-r3) are also expressed in the pituitary and one $\mathrm{GnIH}$ receptor gene (gnih-r3) is present in the ovary (16). In the grass puffer and the tilapia, the GnIH receptor is expressed in the brain and pituitary, the latter species also exhibiting GnIH-R transcripts in the ovary, liver, anterior, and posterior intestine, fat, muscle, and heart $(17,58)$. GnIH-R
mRNA was primarily detected in the brain, pituitary, retina, and gonad of cinnamon clownfish, Amphiprion melanopus (60). To date, the precise cellular localization of GnIH-Rs has only been elucidated in the gonads of goldfish by using in situ hybridization (59), and in the brain and pituitary of tilapia by using a combination of in situ hybridization and immunohistochemistry $(17,42)$. In goldfish, GnIH-R1 and 2 were localized exclusively to the oocytes before the cortical alveolus stage and to the interstitial tissue to the testis (59). Tilapia GnIH-R-ir cells were distributed widely in the brain, being evident in the olfactory bulbs, dorsal and ventral telencephalic areas, preoptic area, ventral and dorsal thalamus, pretectum, pregromerular area, tuberal hypothalamus, lateral recess, dorsal tegmentum, periventricular gray zone of optic tectum, semicircular torus, posterior tuberal region, granular, and molecular layers of the corpus of the cerebellum, reticular area, superior raphe, and central gray (42). In the tilapia pituitary, immunoreactive GnIH-R cells lie in the dorsal and ventral parts of the rostral pars distalis, and the pars intermedia. In the ventral part of the proximal pars distalis, LH cells were labeled with the GnIH-R antiserum, whereas only a few FSH cells from the dorsal part of the proximal pars distalis appeared immunostained. ACTH cells from the rostral pars distalis and $\alpha$-MSH cells from the pars intermedia also exhibited GnIH-R immunoreactivity (42). The distribution of GnIH-R-ir cells and/or GnIH-ir fibers in the pituitary of tilapia and sea bass could suggest a role of $\mathrm{GnIH}$ not only in reproduction but also in the stress response and growth/metabolism of fish.

\section{PHYSIOLOGICAL ACTIONS OF GnIH IN FISH}

The physiological actions of $\mathrm{GnIH}$ and related peptides in fish are summarized in Table 2. As it has been described in many studies and reviews, the reproductive inhibitory effects of $\mathrm{GnIH}$ were first established in birds and mammals through its reported actions on GnRH and gonadotropin synthesis and secretion $(1-3,61)$. However, the role of GnIH orthologs in reproduction remains controversial in fish and, as indicated above, the observed inhibitory or stimulatory effects of GnIH could be dependent on the species, sex, reproductive strategies and stages, the peptides used, dose, their route of administration and/or the elapsed time after treatment (Figure 3). 
TABLE 2 | Molecular structure and physiological actions of GnlH in teleost fish.

\begin{tabular}{|c|c|c|c|c|}
\hline $\begin{array}{l}\text { Common name } \\
\text { of species }\end{array}$ & $\begin{array}{l}\text { Common } \\
\text { classification }\end{array}$ & Putative peptide sequence & Physiological action & Reference \\
\hline \multirow[t]{15}{*}{ Goldfish } & \multirow[t]{5}{*}{$g f G n I H-1$} & \multirow[t]{5}{*}{ PTHLHANLPLRFa } & $\begin{array}{l}\text { Stimulation of pituitary FSH, LH and GH release (gfGnlH-1,-2,-3, in vitro; } \\
\text { sockeye salmon) }\end{array}$ & Amano et al. (15) \\
\hline & & & $\begin{array}{l}\text { Stimulation of pituitary } I h \beta, f s h \beta, p r l \text {, and } g h \text { synthesis ( } g f G n l H-1 \text {, } \\
\text { in vitro; grass puffer) }\end{array}$ & $\begin{array}{l}\text { Shahjahan et al. } \\
(58,62)\end{array}$ \\
\hline & & & $\begin{array}{l}\text { Inhibition of gnrh-3 and } f \operatorname{sh} \beta \text { synthesis (gfGnlH-2,-3, in vivo ip; female } \\
\text { goldfish) }\end{array}$ & Qi et al. (57) \\
\hline & & & Inhibition of Ih $\beta$ synthesis (gfGnlH-2, in vivo ip; female goldfish) & Qi et al. (57) \\
\hline & & & $\begin{array}{l}\text { Inhibition of } \mathrm{GnRH} \text {-stimulated pituitary } \operatorname{lh} \beta \text { and } f \operatorname{sh} \beta \text { synthesis (gfGnlH-3, } \\
\text { in vitro; mixed sex goldfish) }\end{array}$ & Qi et al. (57) \\
\hline & \multirow[t]{5}{*}{$g f G n / H-2$} & \multirow[t]{5}{*}{ AKSNINLPQRFa } & $\begin{array}{l}\text { Increase of plasma testosterone levels (gfGnlH-2,-3, in vivo ip; male } \\
\text { goldfish) }\end{array}$ & Qi et al. (59) \\
\hline & & & $\begin{array}{l}\text { Stimulation of star and } 3 \beta h s d \text { synthesis (gfGnlH-2,-3, in vivo ip; male } \\
\text { goldfish) }\end{array}$ & Qi et al. (59) \\
\hline & & & Inhibition of cyp19 synthesis (gfGnlH-2,-3, in vivo ip; male goldfish) & Qi et al. (59) \\
\hline & & & $\begin{array}{l}\text { Stimulation of } f \text { sh-r, Ih-r, star, and } 3 \beta h s d \text { synthesis (gfGnlH-2,-3, in vitro; } \\
\text { male goldfish) }\end{array}$ & Qi et al. (59) \\
\hline & & & $\begin{array}{l}\text { Stimulation or inhibition of } \mathrm{LH} \text { release, } / h \beta, f s h \beta \text {, and/or gnih-r expression } \\
\text { depending on the maturational status and administration route (gfGnlH-3, } \\
\text { in vivo ip and in vitro; mixed sex goldfish) }\end{array}$ & $\begin{array}{l}\text { Moussavi } \\
\text { et al. }(19,20,63)\end{array}$ \\
\hline & \multirow[t]{5}{*}{$g f G n / H-3$} & \multirow[t]{5}{*}{ SGTGLSATLPQRFa } & $\begin{array}{l}\text { Attenuation of GnRH-2 and GnRH-3 effects on } \mathrm{LH} \text { secretion and } \\
\text { gonadotropin subunit mRNA levels in particular reproductive stages } \\
\text { (gfGnlH-3, in vivo ip and in vitro; mixed sex goldfish) }\end{array}$ & $\begin{array}{l}\text { Moussavi } \\
\text { et al. (20) }\end{array}$ \\
\hline & & & $\begin{array}{l}\text { Inhibition of GH release and stimulation of } g h \text { expression (gfGnlH-3, in vivo } \\
\text { ip; mixed sex goldfish) }\end{array}$ & $\begin{array}{l}\text { Moussavi } \\
\text { et al. (63) }\end{array}$ \\
\hline & & & $\begin{array}{l}\text { Attenuation of } \mathrm{GnRH}-2 \text { and } \mathrm{GnRH}-3 \text { effects on } \mathrm{GH} \text { release and gh } \\
\text { expression in a reproductive-dependent manner (gfGnlH-3, in vivo ip and } \\
\text { in vitro; mixed sex goldfish) }\end{array}$ & $\begin{array}{l}\text { Moussavi } \\
\text { et al. (63) }\end{array}$ \\
\hline & & & $\begin{array}{l}\text { Inhibition of plasma levels of } \mathrm{GnRH}, \mathrm{FSH} \text { and } \mathrm{LH} \text {, and } \operatorname{sbgnrh}, \mathrm{Ih} \beta \text {, fsh } \beta \text {, and } \\
\text { gth } \alpha \text { expression (gfGnlH-3, in vivo ip; immature, male and female cinnamon } \\
\text { clownfish). }\end{array}$ & Choi et al. (60) \\
\hline & & & $\begin{array}{l}\text { Stimulation of gnih, gnih-r and melatonin receptor expression, and of } \\
\text { plasma levels of melatonin (gfGnlH-3, in vivo ip; immature, male and female } \\
\text { cinnamon clownfish) }\end{array}$ & Choi et al. (60) \\
\hline \multirow[t]{3}{*}{ Zebrafish } & \multirow[t]{3}{*}{ zfGnIH-3 } & \multirow[t]{3}{*}{ SGTGPSATLPQRFa } & Decreases in plasma LH level (in vivo ip; female goldfish). & Zhang et al. (16) \\
\hline & & & Reduction of gnrh-3 expression (in vitro, adult male brain slices of zebrafish). & Spicer et al. (48) \\
\hline & & & $\begin{array}{l}\text { Downregulation of } / h \beta \text { and common } \alpha \text { subunit expression (in vitro, adult } \\
\text { male pituitary explants of zebrafish) }\end{array}$ & Spicer et al. (48) \\
\hline \multirow{2}{*}{$\begin{array}{l}\text { cichlid fish } \\
\text { Cichlasoma } \\
\text { dimerus }\end{array}$} & $c d G n / H-1$ & TPNSSPNLPQRFa & $\begin{array}{l}\text { Inhibition of } \mathrm{LH} \beta \text { and } \mathrm{FSH} \beta \text { release and stimulation of } \mathrm{GH} \text { release } \\
\text { (cdGnlH-1, in vitro; mixed sex cichlid) }\end{array}$ & Di Yorio et al. (44) \\
\hline & $c d G n / H-2$ & APNQVLPQRFa & Stimulation of $\mathrm{FSH} \beta$ release (cdGnlH-2 in vitro; mixed sex cichlid) & Di Yorio et al. (44) \\
\hline Tilapia & tiGnIH-2 & QSDERTPNSSPNLPQRFa & $\begin{array}{l}\text { Stimulation of } \mathrm{LH} \text { and } \mathrm{FSH} \text { release (tiGnlH-2, in vivo ip and in vitro; female } \\
\text { tilapia). }\end{array}$ & Biran et al. (17) \\
\hline \multirow{5}{*}{$\begin{array}{l}\text { Orange-spotted } \\
\text { grouper }\end{array}$} & $g r G n l H-1$ & LFPPTAKPFQLHANMPMRFa & Inhibition of gnrh-1 synthesis (grGnlH-1,-2,-3, in vivo ip; female grouper) & Wang et al. (64) \\
\hline & grGnIH-2 & ESVPGDDSAPNSTPNMPQRFa & Inhibition of Ih $\beta$ synthesis (grGnlH-2, in vivo ip; female grouper) & Wang et al. (64) \\
\hline & \multirow[t]{3}{*}{ grGn/H-3 } & \multirow[t]{3}{*}{ EAQNPILPQRL } & Stimulation of gnrh-3 synthesis (grGnlH-3, in vivo ip; female grouper) & Wang et al. (64) \\
\hline & & & Stimulation of $/ h-r$ synthesis (grGnlH-2, in vitro; female grouper) & Wang et al. (65) \\
\hline & & & $\begin{array}{l}\text { Stimulation of star and } 3 \beta h s d 1 \text { synthesis ( } g r G n l \mathrm{H}-1 \text {, in vivo ip and in vitro; } \\
\text { female grouper) }\end{array}$ & Wang et al. (65) \\
\hline Sea bass & $s b G n / H-1$ & PLHLHANMPMRFa & $\begin{array}{l}\text { Inhibition of brain gnrh2, kiss 1, kiss2, kiss 1-r, gnih, and gnih-r expression } \\
\text { (sbGnlH-2 in vivo icv; male sea bass) }\end{array}$ & $\begin{array}{l}\text { Paullada-Salmerón } \\
\text { et al. (18) }\end{array}$ \\
\hline
\end{tabular}


TABLE 2 | Continued

\begin{tabular}{|c|c|c|c|c|}
\hline $\begin{array}{l}\text { Common name } \\
\text { of species }\end{array}$ & $\begin{array}{l}\text { Common } \\
\text { classification }\end{array}$ & Putative peptide sequence & Physiological action & Reference \\
\hline & \multirow[t]{6}{*}{$s b G n / H-2$} & \multirow[t]{6}{*}{ SPNSTPNMPQRFa } & Inhibition of brain gnrh-1 expression (sbGnIH-1 in vivo icv; male sea bass) & $\begin{array}{l}\text { Paullada-Salmerón } \\
\text { et al. (18) }\end{array}$ \\
\hline & & & $\begin{array}{l}\text { Inhibition of pituitary } f s h \beta, I h \beta, g h \text {, and gnrh-r-II-1a expression (sbGnlH-1,-2 } \\
\text { in vivo icv, im; male sea bass) }\end{array}$ & $\begin{array}{l}\text { Paullada-Salmerón } \\
\text { et al. }(18,66)\end{array}$ \\
\hline & & & Decreases in plasma LH levels (sbGnlH-1,-2 in vivo icv, im; male sea bass) & $\begin{array}{l}\text { Paullada-Salmerón } \\
\text { et al. }(18,66)\end{array}$ \\
\hline & & & Decreases in plasma FSH levels (sbGnlH-1 in vivo im; male sea bass) & $\begin{array}{l}\text { Paullada-Salmerón } \\
\text { et al. (66) }\end{array}$ \\
\hline & & & $\begin{array}{l}\text { Decreases in plasma T and 11-KT levels (sbGnlH-1, } 2 \text { in vivo im; male sea } \\
\text { bass) }\end{array}$ & $\begin{array}{l}\text { Paullada-Salmerón } \\
\text { et al. (66) }\end{array}$ \\
\hline & & & Increases in diurnal activity (sbGnlH-1,-2 in vivo im; male sea bass) & $\begin{array}{l}\text { Paullada-Salmerón } \\
\text { et al. (66) }\end{array}$ \\
\hline
\end{tabular}

Characteristic C-terminal five amino acid sequences are highlighted in bold. icv, intracerebroventricular injection; im, intramuscular injection; ip, intraperitoneal injection.

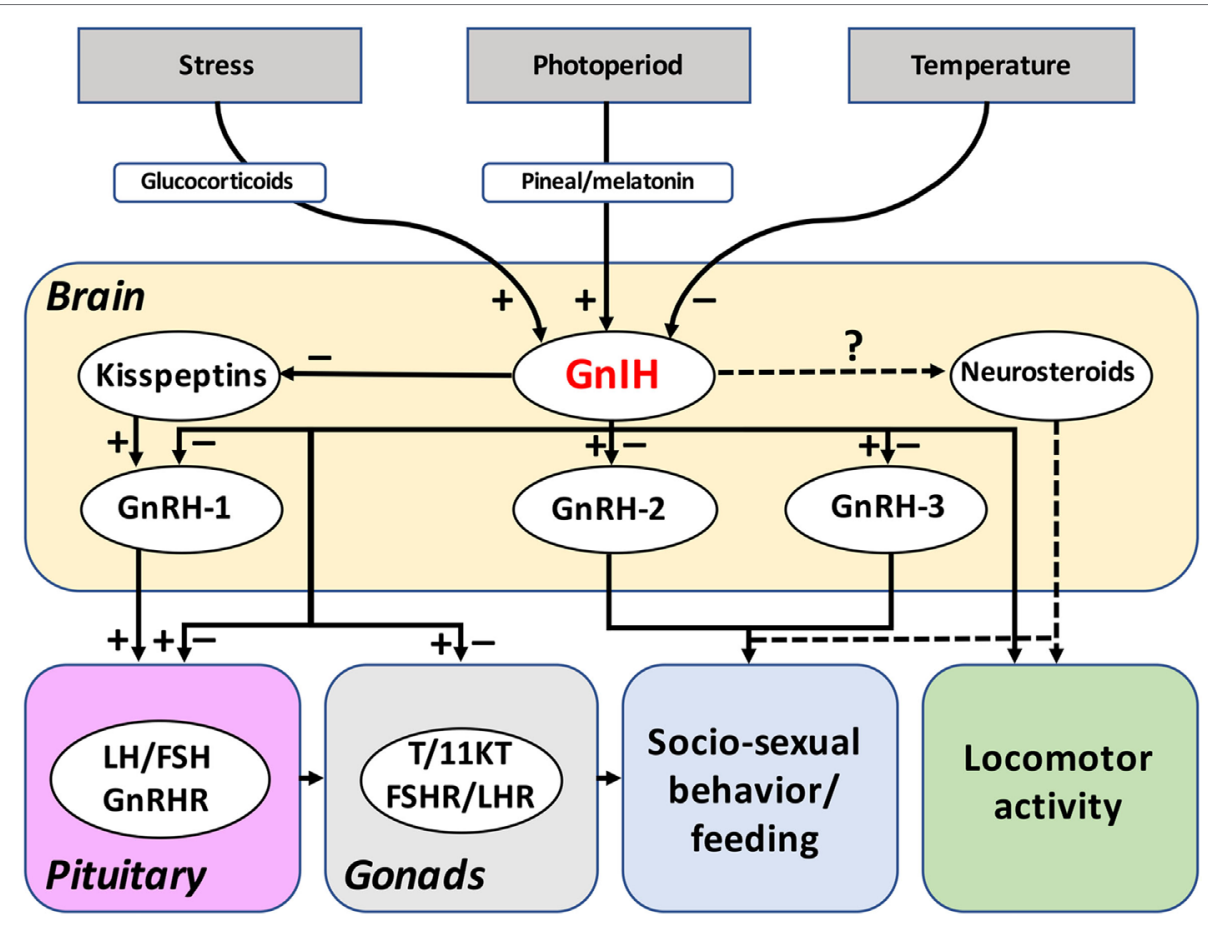

FIGURE 3 | Reported functions and regulation of GnlH system in fish. The reported actions of GnlH on the brain-pituitary-gonad axis of fish are summarized in this figure. Most of the studies have been concentrated on $\mathrm{GnIH}$ actions on gonadotropin synthesis and release, evidencing both inhibitory and stimulatory effects. In contrast, only a few studies have addressed the effects of $\mathrm{GnlH}$ on neuroendocrine systems and in gonadal physiology in fish. The putative actions of GnlH in fish behavior (socio-sexual behavior, locomotor activity) and feeding could be mediated by its effects on GnRH-2, GnRH-3, kisspeptins, and/or neurosteroids synthesis. Evidences obtained suggest that GnlH could also be mediating the effects of photoperiod, temperature, and stress on the reproductive and other axes of fish, as it has been reported in birds and mammals. Dotted lines refer to suspected actions. Abbreviations: FSH, follicle-stimulating hormone; FSHR, FSH receptor; GnlH, gonadotropin-inhibitory hormone; GnRH, gonadotropin-releasing hormone; GnRHR, GnRH receptor; LH, luteinizing hormone; LHR, LH receptor; T, testosterone; $11 \mathrm{KT}, 11$-ketotestosterone.

\section{GnIH Actions on Neuroendocrine Systems in Fish}

The presence of profuse GnIH fiber projections and/or their receptors in the ventral telencephalon, the preoptic area, and the hypothalamus of several fish species $(8,15,41-43,57)$ suggests that GnIH might be acting at the central level to modulate the main neuroendocrine systems controlling the reproductive process. To date, most of the reported effects of different $\mathrm{GnIH}$ orthologs on brain neuroendocrine systems are inhibitory (Table 2). For example, icv injection of sbGnIH-1 in mature male sea bass, and intraperitoneal (ip) injections of grouper $\mathrm{GnIH}$ (grGnIH)-1, -2, and -3 in female grouper (Epinephelus 
coioides), and of goldfish GnIH (gfGnIH)-3 in inmature, male and female cinnamon clownfish decreased gnrh-1 mRNA levels, the latter species also exhibiting reduced plasma $\mathrm{GnRH}$ levels after $\mathrm{GnIH}$ treatment $(41,60,64)$. In mature male sea bass, the effects of $\mathrm{GnIH}$ on GnRH-2 expression appear dependent of the route of administration because centrally (icv)-administered sbGnIH-2 reduced gnrh-2 mRNA levels, whereas the same $\mathrm{GnIH}$ form injected peripherally (intramuscular) increased the gnrh-2 expression $(18,66)$. In turn, gfGnIH-2 and gfGnIH-3 peptides inhibited the expression of gnrh-3 gene, having no effects on gnrh-2 transcript levels in female goldfish (57), and zebrafish GnIH (zfGnIH)-3 reduced gnrh-3 expression in brain slices of zebrafish (48), but stimulatory effects of grGnIH-3 on gnrh-3 expression have been reported in ip-injected female groupers (64). The kisspeptin system of sea bass is also modulated by $\mathrm{GnIH}$ where sbGnIH-2 icv-injected animals exhibited decreased kiss1, kiss2, and kiss1r transcript levels (18). These results are consistent with the presence of abundant GnIH-ir fibers in the habenula, preoptic area, rostral mediobasal hypothalamus and around the lateral recess of sea bass, where Kiss1 and Kiss2 neurons are present $(41,50)$. Results obtained in cinnamon clownfish and sea bass showed that GnIH can also modulate brain gnih and gnih-r mRNA levels, indicating the existence of an autocrine regulation on the brain $\mathrm{GnIH}$ system $(18,41,60)$. However, the nature of these autoregulatory actions seems to be dependent on the route of administration because centrally (icv)-injected sbGnIH-2 decreased gnih and gnih-r expression in sea bass (18), whereas peripherally (intramuscular or intraperitoneal)-administrated sbGnIH-2 and gfGnIH-3 increased gnih and gnih- $r$ mRNA levels in cinnamon clownfish and sea bass, respectively $(41,60)$.

\section{Role of GnIH in Fish Pituitary}

The distribution pattern of GnIH fibers and its receptors described above reinforces the involvement of this neuropeptide in the regulation of pituitary hormone synthesis and secretion in fish (Figure 3). The first physiological study developed in teleost fish demonstrated that in vitro treatment of cultured pituitary cells with exogenous $\mathrm{GnIH}$ (goldfish GnIH-1, -2, and -3 peptides) stimulated the release of LH and FSH in sockeye salmon (15). Likewise, in vitro treatment with gfGnIH-1 enhanced $f s h \beta$ and $\operatorname{lh} \beta$ gene expression in grass puffer pituitary (58) and Cichlasoma dimerus $\mathrm{GnIH}$ (cdGnIH)-2 peptide also provoked an increase of in vitro $\mathrm{FSH}-\beta$ release in intact pituitary cultures of this cichlid fish (44). In female tilapia, both in vivo and in vitro studies revealed that tiGnIH-2 induced a significant increase in FSH and LH secretion (17).

On the other hand, in vivo and in vitro studies performed in goldfish examining the effects of gfGnIH-3 on pituitary $\ln \beta, f_{s h} \beta$, and gnih-r mRNA levels, as well as on LH secretion showed mixed results $(19,20)$. Intraperitoneal (ip) injection of gfGnIH-3 peptide reduced LH plasma levels at early- and midgonadal recrudescence, as well as the expression of gnih- $r$ mRNA levels in the pituitary at mid-late and late recrudescence stages, but increased the mRNA levels of both $\operatorname{lh} \beta$ and $f \operatorname{sh} \beta$ at early to late recrudescence. Furthermore, the incubation of cultured pituitary cells with gfGnIH-3 provoked a decrease of $\operatorname{lh} \beta$ and $f_{s h} \beta$ transcript levels at early and late recrudescence, but elevated the gene expression of $\operatorname{lh} \beta$ at mid-recrudescence and stimulated the LH secretion at late-gonadal recrudescence. Moussavi and colleagues have further investigated the interaction of gfGnIH-3 with two forms of GnRH, GnRH-2 and GnRH-3, both in vivo and in vitro (20). Administration of gfGnIH-3 or GnRH alone evoked an increase of $\operatorname{lh} \beta$ and $f \operatorname{sh} \beta$ mRNA levels at early-, mid-, and lategonadal recrudescence, but gfGnIH-3 treatment showed no effect on transcription of $\operatorname{lh} \beta$ gene at late recrudescence. Conversely, co-injection of gfGnIH-3 with GnRH-3 reduced the expression of $\operatorname{lh} \beta$ mRNA levels at early recrudescence, and $\operatorname{lh} \beta$ and $f \operatorname{sh} \beta$ mRNA levels during mid- and late-gonadal recrudescence, whereas the co-treatment of gfGnIH-3 with GnRH-2 decreased the transcript levels of $\operatorname{lh} \beta$ at mid and late recrudescence. Additionally, during early- and mid-gonadal recrudescence, treatment with gfGnIH-3 caused an inhibition of plasma LH levels, and this reduction was also observed in fish co-injected with GnRH-2 or GnRH-3 in early gonadal recrudescence. Treatments with GnRH-2 and GnRH-3 stimulated gnih- $r$ expression at mid and late recrudescence, while opposite effects, i.e., reduced gnih- $r$ mRNA levels, were observed after gfGnIH-3 treatment during late recrudescence. In vitro experiments showed that exposure to gfGnIH-3 suppressed GnRH-2-induced LH response at mid recrudescence. Taken together, these results suggest that GnIH in goldfish can exert complex stimulatory or inhibitory effects on gonadotropin synthesis and secretion, as well as on GnRH regulation of this pituitary function, depending on the reproductive stage of the animals and administration route $(19,20)$.

In contrast, inhibitory effects of $\mathrm{GnIH}$ on gonadotropins have been reported in other studies performed in species such as goldfish, cinnamon clownfish, cichlid C. dimerus, orangespotted grouper, sea bass, and zebrafish $(16,18,44,48,57$, $60,64,66)$. The ip administration of $\mathrm{zfGnIH}-3$ decreased $\mathrm{LH}$ plasma levels in female goldfish at 1 and $3 \mathrm{~h}$ post injection at the highest doses tested (16). Another in vivo study performed in female goldfish showed that animals treated with gfGnIH-2 and gfGnIH-3 peptides had reduced $f_{s h} \beta$ mRNA levels in the pituitary gland, while only the gfGnIH-2 form was able to decrease $\operatorname{lh} \beta$ expression significantly (57). Nevertheless, in vitro administration of gfGnIH-2 and gfGnIH-3 in cultured pituitary cells, although it had no effect on either $f \operatorname{sh} \beta$ or $\operatorname{lh} \beta$ mRNA levels, decreased GnRH-stimulated $f \operatorname{sh} \beta$ and $\operatorname{lh} \beta$ expression (57). In the pituitary gland of the female grouper, injections of grGnIH-2 peptide decreased $\operatorname{lh} \beta$ mRNA levels (64). In 2016, Choi and collaborators also evaluated the effects of $\mathrm{GnIH}$ on transcript and plasma levels of gonadotropins in immature, and mature male and female cinnamon clownfish showing that ip injection with heterologous gfGnIH-3 reduced $g t h \alpha, f s h$, and $\operatorname{lh} \beta$ expression, as well as plasma FSH and LH (60). In the cichlid fish Cichlasoma dimerus, cdGnIH-1 peptide also inhibited LH $\beta$ and FSH $\beta$ release in intact pituitary cultures (44). Recent studies performed in the male sea bass showed that treatment with both sbGnIH-1 and sbGnIH-2 peptides exerted inhibitory actions on the synthesis and release of gonadotropins $(18,66)$. Findings revealed that the central (18) and peripheral (66) administration of sbGnIH-1 or sbGnIH-2 peptides reduced LH plasma levels, as well as pituitary $\operatorname{lh} \beta$ mRNA levels. Furthermore, only the icv injection 
with sbGnIH-2 determined a reduction of pituitary $f \operatorname{sh} \beta$ and gnrh-r-II-1a receptor mRNA levels (18), whereas intramuscular administration of sbGnIH-1 elicited a decrease in FSH plasma levels (66). In pituitary explants, $\mathrm{zfGnIH-3}$ downregulated $\operatorname{lh} \beta$ and common $\alpha$ subunit expression (48).

In addition to its effects on gonadotropins, $\mathrm{GnIH}$ has also been shown to be involved in the regulation of the synthesis and/or release of other adenohypophyseal hormones in fish. A pioneer study performed in sockeye salmon showed that in vitro treatment of cultured pituitary cells with the three goldfish $\mathrm{GnIH}$ peptides (gfGnIH-1, -2, and -3) stimulated GH release (15). Accordingly, in vitro gfGnIH-1 increased gh transcript levels, as well as those of prolactin, in grass puffer (62) and cdGnIH-1 augmented the release of GH in pituitary cultures of a cichlid species (44). However, ip injection of tiGnIH-2 did not show any change in GH release in female tilapia (17). Another study in goldfish showed that ip injection of gfGnIH-3 reduced GH plasma levels at early, mid, and late recrudescence, but elevated $g h$ gene expression in the pituitary (63). These authors also showed that gfGnIH-3 attenuates the effects of GnRH-2 and GnRH-3 on $\mathrm{GH}$ release and $g h$ expression in a reproductive-related manner (63). Icv injections of sbGnIH-2 inhibited $g h$ mRNA levels in a dose dependent manner in male sea bass (18). The presence of GnIH fibers in the proximal pars distalis of the sea bass pituitary, innervating $\mathrm{GH}$-ir cells, and in the pars intermedia (41), as well as coursing close to somatolactin, $\alpha$-MSH and ACTH cells of tilapia, the two latter cell types also exhibiting GnIH-receptor immunoreactivity (42), reinforces the assumption that $\mathrm{GnIH}$ can modulate the synthesis and secretion of some pituitary hormones other than gonadotropins.

\section{Role of GnIH on Gonadal Physiology}

It has been demonstrated that not only the brain, but also the gonads may be a source of GnIH. Based on different studies in birds and mammals (67-71), GnIH has also been considered as a peripheral regulator of gonadal functions. The fish gonads also synthesize $\mathrm{GnIH}$, as reflected in different studies showing gnih expression in the ovary and/or the testis of zebrafish, tilapia and sea bass $(16,17,41,47)$. Recently, gnih transcripts were identified in the cortical vesicles of previtellogenic oocytes of zebrafish, as well as in the follicular cells and in the zona radiata of the vitellogenic oocytes (47). Although the expression of GnIH and GnIH-R has been reported in the gonads of different teleost species $(16,17,41,47,59,65)$, most of the research has been focused on $\mathrm{GnIH}$ actions in gonadotropin synthesis and secretion, and only a few studies have addressed the role of $\mathrm{GnIH}$ in gonadal gametogenesis and/or steroidogenesis of fish $(59,65,66)$. Qi and collaborators (59) studied the effects of GnIH on steroidogenesis in male and female goldfish gonads. Implantation of gfGnIH-2 or gfGnIH-3 did not induce any change in estradiol plasma levels in females, but both $\mathrm{GnIH}$ peptides increased serum testosterone levels in male goldfish. Additionally, ip injection with both $\mathrm{GnIH}$ forms enhanced the gene expression of steroidogenic acute regulatory protein (star) and $3 \beta$-hydroxysteroid dehydrogenase ( $3 \beta$ hsd) genes and decreased cyp19 mRNA levels in the testes of the goldfish. In vitro analysis using gfGnIH-2 and gfGnIH-3 in cultured testicular cells also significantly increased $f_{s h}, \mathrm{lhr}$, star, and $3 \beta h s d$ transcript levels, but reduced cyp19 expression. However, ovarian mRNA levels of gonadotropin receptors and steroid-synthesizing enzymes were unaffected after both in vivo and in vitro $\mathrm{GnIH}$ treatments (59). In contrast, in a recent study performed in female grouper, treatment with grGnIH-2 increased $l h r$ mRNA levels in cultured ovary fragments, and grGnIH-1 peptide stimulated the ovarian expression of star and $3 \beta$ hsd both in vitro and in vivo (65). On the other hand, the peripheral sbGnIH-1 and sbGnIH-2 implants in male European sea bass caused an inhibition of testosterone and 11-ketotestosterone plasma levels at particular reproductive stages (early- and mid-spermatogenesis), without affecting plasma levels of the progestin 17,20 3 -dihydroxy-4pregnen-3-one (66). Moreover, intramuscular implant of both $\mathrm{GnIH}$ peptides determined a delay in the development of testis, which exhibited abundant type A spermatogonia (SgA) and only scattered and isolated clusters of spermatozoids at the spermiation phase (66). Taken together, these findings suggest that $\mathrm{GnIH}$ may regulate the reproductive axis of teleost fish by acting not only at the brain and pituitary levels but also on gonadal physiology, the nature of its actions depending on the species, the sex and the reproductive stage (Figure 3 ).

\section{Role of GnIH in Fish Behavior}

First reports of $\mathrm{GnIH}$ effects on socio-sexual behavior and/ or sexual motivation were obtained in birds $(34,72,73)$ and mammals $(51,74)$. Despite many studies that have explored the interactions between $\mathrm{GnIH}$ and the reproductive axis, how $\mathrm{GnIH}$ is involved in the regulation of reproductive, social and other behaviors in fish is still almost unknown. To date, the only study addressing the role of $\mathrm{GnIH}$ in fish behavior has been accomplished in the European sea bass (66), showing that both sbGnIH-1 and sbGnIH-2 affected the diurnal to nocturnal ratio of locomotor activity along the reproductive cycle. In this study, whereas control animals progressively decreased their diurnal habits as spermatogenesis progressed and they reached the spermiation phase, GnIH treatment induced a significant elevation in their diurnal pattern of activity along the same gametogenic stages, and this diurnal activity only decreased when the $\mathrm{GnIH}$ treatment ceased at the spawning season (66). It is interesting to note that the European sea bass is a rhythmic species that exhibits diurnal feeding and locomotor activity patterns during most of the year, but switches to nocturnal during the reproductive season at winter $(75,76)$. Moreover, diencephalic expression of gnih in sea bass was higher during the resting season and lower during the reproductive season (55). Therefore, it is plausible to consider that this seasonal pattern of GnIH expression could be on the basis of this natural diurnal to nocturnal shift observed in the reproductive season of this species.

As indicated above, the midbrain of Indian major carp and European sea bass contains a GnIH cell population located in the dorsal mesencephalic tegmentum $(41,43)$. Based on their location and the profuse $\mathrm{GnIH}$ innervation in sensory-motor areas, a role in regulating behavior (locomotor activity, mating, feeding) may be considered for this $\mathrm{GnIH}$ cell population in sea bass $(41,77)$. $\mathrm{GnIH}$ has been found to be involved in the modulation of sociosexual behavior in birds by acting on tegmental GnRH-2 cells, and promoting the conversion of testosterone into neuroestrogens 
via the stimulation of brain cytochrome $\mathrm{P} 450$ aromatase activity $(10,34,73)$. Furthermore, kisspeptin and $\mathrm{GnIH}$ seem also to interact in the regulation of social behavior in mammals and teleosts (78). Interestingly, both sbGnIH-1 and sbGnIH-2 forms decrease plasma testosterone levels, and sbGnIH-2 modulates brain gnrh 2 and kisspeptin gene expression in sea bass $(18,66)$. Several studies performed in fish have reported the potential involvement of neurosteroids in socio-sexual behaviors. For instance, in Lythrypnus dalli, a socially induced decrease in brain aromatase levels resulted in increased aggression (79). In turn, treatments with aromatase inhibitors decreased aggressive behavior in African male cichlid fish Astatotilapia burtoni (80) and reduced courtship activities in male Endler guppy Poecilia reticulata (81). Altogether, these results suggest that $\mathrm{GnIH}$ might also be involved in the regulation of reproductive, social and/ or locomotor behaviors in fish through its actions on GnRH-2, kisspeptins and/or neurosteroid synthesis and release (Figure 3).

\section{REGULATION OF THE GnIH SYSTEM IN FISH}

A range of evidence indicates that the $\mathrm{GnIH}$ system is mediating the effects of photoperiod on different physiological processes in Tetrapods, with results in photoperiodic mammals, birds and amphibians suggesting that its expression is modulated through a melatonin-dependent process $(7,32,38,82,83)$. Unfortunately, much less is known regarding the regulatory mechanisms of $\mathrm{GnIH}$ in fish, although scarce data available support the idea that environmental cues such as photoperiod and temperature are also regulating daily and seasonal profiles of $\mathrm{GnIH}$ in this group of vertebrates (Figure 3).

In general, photoperiodic regulation of reproduction in fish is mediated by plasma melatonin release from the pineal gland, acting at all levels of the reproductive axis $(84,85)$. Data collected in fish also suggest that melatonin might exert its action, at least in part, through GnIH neurons (Figure 3). A recently published study analyzed the relationship between melatonin and $\mathrm{GnIH}$ in the cinnamon clownfish, and reported that $\mathrm{GnIH}$ was co-localized with the melatonin receptor MT-R1 in diencephalic cells (60). Likewise, GnIH cells in sea bass are located in regions known to exhibit melatonin-binding sites $(41,86)$. Bidirectional connections between the pineal organ and $\mathrm{GnIH}$ cells appear to exist in fish, because the pineal organ projects to the NPPv and the dorsal tegmental area, where GnIH cells have been identified in teleosts (87-89), and GnIH-ir fibers have been identified in the fish pineal organ (41). In addition, in grass puffer, the expression of gnih and its receptor showed diurnal and circadian rhythmicity at the spawning stage, in association with melatonin receptor expression, suggesting that the action of $\mathrm{GnIH}$ is cyclic possibly due to regulation by melatonin and the functional role of the $\mathrm{GnIH}$ system is in the regulation of lunar-synchronized spawning $(58,90)$. Interestingly, Cowan and co-workers reported, for the first time in fish, that $\mathrm{GnIH}$ gene expression is regulated by the pineal organ. Their findings in sea bass revealed that pinealectomy $(\mathrm{Px})$ reduced the expression of gnih in a regional(in mid-hindbrain, but not in the telencephalon or diencephalon) and reproductive- (in reproductive season but not in resting) dependent manner (55). Moreover, a seasonal difference in gnih and gnih- $r$ expression was observed in the diencephalon, where both Px and control groups exhibited higher transcript levels of these genes at resting than in the reproductive season (55). All these evidences support the hypothesis that melatonin could play an important role in the regulation of the GnIH system in fish, which could mediate, in turn, in the transduction of environmental information to other reproductive-related systems.

In fish, increasing evidence supports the decisive role of photoperiod and/or temperature on larval development, sex determination/differentiation and puberty (91-94). However, ontogenetic studies of the GnIH system and its developmental regulation by environmental factors have not been adequately addressed in this vertebrate group. In a recent study, PaulladaSalmerón and colleagues performed the first analysis of gnih and gnih receptor expression pattern throughout the first year of life in the European sea bass (95). This study revealed that both gnih and gnih- $r$ showed significantly increased expression from hatching to the second/third week of life, a subsequent decrease in mRNA levels until 120 days post-fertilization (dpf) and then a further increase at the onset of sex differentiation (150 dpf). Afterward, gnih transcript levels dropped significantly during the sex differentiation period (150-240 dpf) and continued at that level for the remainder of that year. The results also revealed daily variations in developmental expression of gnih and gnih- $r$, with higher diurnal mRNA levels at early stages (until $25 \mathrm{dpf}$ ), and a shift to higher nocturnal expression at 300-360 dpf coinciding with the winter (reproductive season) (95). In the same study, Paullada-Salmerón and co-workers further investigated the effects of rearing temperature during the thermosensitive period on the expression of the gnih and its receptor in sea bass. Early exposure to high temperatures $\left(21^{\circ} \mathrm{C}\right)$, which is known to provoke a masculinization of the progeny (96), decreased the levels of gnih and gnih- $r$ transcripts during early development and these effects were also evident at the end of the sex differentiation period (240-300 dpf), indicating that temperature can exert remarkable effects on the transcription of both genes (95). Altogether, these results could indicate that the GnIH system might not only be involved in the modulation of the reproductive cycle but could also be a mediator in sex differentiation and puberty in fish. Involvement of $\mathrm{GnIH}$ in the regulation of reproductive development and puberty has been also studied in birds and mammals $(97,98)$.

Several findings suggest that stress may act through $\mathrm{GnIH}$ neurons to inhibit reproductive function in birds and mammals $(10,99)$. Both acute and chronic stress upregulate hypothalamic $\mathrm{GnIH}$ gene expression in rats, and this stress-induced increase of $\mathrm{GnIH}$ is blocked by adrenalectomy (100). Glucocorticoid receptors are present in $\mathrm{GnIH}$ neurons, as revealed by immunohistochemistry, and could sustain these effects (101). In quail and mice, corticosterone induces $\mathrm{GnIH}$ expression via the glucocorticoid receptor present in $\mathrm{GnIH}$ neurons and these actions appear to be mediated by the glucocorticoid-response element (GRE) present in the promoter of the GnIH gene (101). Although there is no report indicating the involvement of $\mathrm{GnIH}$ in stress response in fish, evidence suggests that a similar mechanism to that reported in Tetrapods may be operating in fish (Figure 3). Promoter 
prediction searching has revealed the presence of several putative GRE in the zebrafish gnih and gnih-r gene promoter sequences (25). Stimulatory effects of cortisol on gnih transcript levels have been reported in the cinnamon clownfish (102). The presence of $\mathrm{GnIH}$-ir fibers in close proximity to $\alpha-\mathrm{MSH}$ and ACTH cells, which also exhibit GnIH-R immunoreactivity, was identified recently in the pituitary of tilapia (42). These results indicate that the role of $\mathrm{GnIH}$ in the mediation of the stress response could be evolutionarily conserved in vertebrates.

\section{CONCLUDING REMARKS}

Increasing research is showing that $\mathrm{GnIH}$ is present throughout the vertebrate lineage from fish to mammals. Most of the teleost GnIH precursor polypeptides identified to date encode three LPXRFamide or LPXRFamide-like peptides, although some species exhibit only two LPXRFamide-like peptide sequences. The presence of a diencephalic GnIH cell population in the preoptic area/hypothalamus, the profuse $\mathrm{GnIH}$ innervation in the brain and the hypophysiotropic character of $\mathrm{GnIH}$ seem also to represent a common feature for all vertebrate groups, including fish. However, recent studies in teleosts are revealing that GnIH cells can also be found in cells from the olfactory bulbs, ventral telencephalon, dorsal midbrain tegmentum, and rostral rhombencephalon, likely to be coexisting with other RFamide neuropeptides. Functional studies of GnIH in fish have mainly focused on its effects on gonadotropin synthesis and secretion, but increasing evidence is showing that it can also regulate reproduction by modulating brain $\mathrm{GnRH}$ and kisspeptin systems, as well as gonadal gametogenesis and steroidogenesis. Contrary to that referenced in birds and mammals, in which inhibitory actions of $\mathrm{GnIH}$ represent the main feature, both inhibitory and stimulatory actions of $\mathrm{GnIH}$ have been reported in the reproductive axis of fish (Figure 3). This diversity in actions could be related to the species, the sex of the animals, the physiological status, the route, and the time elapsed after administration of the GnIH peptide. Nevertheless, the results obtained in a recent dose-response study (18), as well as in work analyzing the

\section{REFERENCES}

1. Tsutsui K, Saigoh E, Ukena K, Teranishi H, Fujisawa Y, Kikuchi M, et al. A novel avian hypothalamic peptide inhibiting gonadotropin release. Biochem Biophys Res Commun (2000) 275(2):661-7. doi:10.1006/bbrc. 2000.3350

2. Ubuka T, Ukena K, Sharp PJ, Bentley GE, Tsutsui K. Gonadotropin-inhibitory hormone inhibits gonadal development and maintenance by decreasing gonadotropin synthesis and release in male quail. Endocrinology (2006) 147(3):1187-94. doi:10.1210/en.2005-1178

3. Kriegsfeld LJ, Mei DF, Bentley GE, Ubuka T, Mason AO, Inoue K, et al. Identification and characterization of a gonadotropin-inhibitory system in the brains of mammals. Proc Natl Acad Sci U S A (2006) 103(7):2410-5. doi:10.1073/pnas.0511003103

4. Murakami M, Matsuzaki T, Iwasa T, Yasui T, Irahara M, Osugi T, et al. Hypophysiotropic role of RFamide-related peptide-3 in the inhibition of LH secretion in female rats. J Endocrinol (2008) 199(1):105-12. doi:10.1677/ JOE-08-0197

5. Kadokawa H, Shibata M, Tanaka Y, Kojima T, Matsumoto K, Oshima K, et al. Bovine C-terminal octapeptide of RFamide-related peptide-3 suppresses ligand dose-dependent activation of GPR147/GPR74 receptors by GnIH and NPFF (46), suggest that the GnIH actions on the reproductive axis of fish could be inhibitory at low (physiological) concentrations, and stimulatory at higher (pharmacological) concentrations, which could also explain the diversity of $\mathrm{GnIH}$ actions reported in fish studies. Whether centrally- and peripherally- (e.g., gonadal) synthesized GnIH exert different effects on reproduction and other physiological processes remains an open question. Reinforcing and building on the knowledge acquired in the last decade on $\mathrm{GnIH}$ in fish will require further efforts to clarify the role of this RFamide neuropeptide in functions other than reproduction, such as feeding, stress response, and behavior, as well as in elucidating the intracellular pathways and regulatory mechanisms involved in $\mathrm{GnIH}$ actions.

\section{AUTHOR CONTRIBUTIONS}

All authors listed have made a substantial, direct, and intellectual contribution to the work and approved it for publication.

\section{ACKNOWLEDGMENTS}

We thank Dr. E. Mañanos, Dr. S. Zanuy, Dr. J. F. López-Olmeda, Dr. A. Gomez, and Dr. F. J. Sánchez-Vázquez for their contribution toward a number of the studies carried out on the sbGnIH system reported in this review.

\section{FUNDING}

This work was supported by grants from the Junta de Andalucía (grant no. P10-AGR-05916), MINECO (grants no. AGL201022139-C03-02, AGL2013-49027-C3-2-R) and Universidad de Cádiz (Plan Propio, grants no. AT2014-020, AT2016-014, AT2017-009) to JM-C. JP-S is a postdoctoral fellow from the Junta de Andalucía. MA-G was recipient of a predoctoral fellowship from MINECO. MC was recipient of a Marie Curie postdoctoral contract from the European Union's Seventh Framework Programme (FP7/2007-2013, grant no. 331964).

luteinizing hormone $(\mathrm{LH})$ secretion from the pituitary as well as pulsatile LH secretion in bovines. Domest Anim Endocrinol (2009) 36(4):219-24. doi:10.1016/j.domaniend.2009.02.001

6. Ubuka T, Lai H, Kitani M, Suzuuchi A, Pham V, Cadigan PA, et al. Gonadotropin-inhibitory hormone identification, cDNA cloning, and distribution in rhesus macaque brain. J Comp Neurol (2009) 517(6):841-55. doi: $10.1002 / \mathrm{cne} .22191$

7. Ubuka T, Inoue K, Fukuda Y, Mizuno T, Ukena K, Kriegsfeld LJ, et al. Identification, expression, and physiological functions of Siberian hamster gonadotropin-inhibitory hormone. Endocrinology (2012) 153(1):373-85. doi:10.1210/en.2011-1110

8. Sawada K, Ukena K, Satake H, Iwakoshi E, Minakata H, Tsutsui K. Novel fish hypothalamic neuropeptide. Eur J Biochem (2002) 269(24):6000-8. doi:10.1046/j.1432-1033.2002.03351.x

9. Osugi T, Son YL, Ubuka T, Satake H, Tsutsui K. RFamide peptides in agnathans and basal chordates. Gen Comp Endocrinol (2016) 227:94-100. doi:10.1016/ j.ygcen.2015.06.012

10. Ubuka T, Son YL, Tsutsui K. Molecular, cellular, morphological, physiological and behavioral aspects of gonadotropin-inhibitory hormone. Gen Comp Endocrinol (2016) 227:27-50. doi:10.1016/j.ygcen.2015.09.009 
11. Osugi T, Okamura T, Son YL, Ohkubo M, Ubuka T, Henmi Y, et al. Evolutionary origin of GnIH and NPFF in chordates: insights from novel amphioxus RFamide peptides. PLoS One (2014) 9(7):e100962. doi:10.1371/journal. pone.0100962

12. Osugi T, Daukss D, Gazda K, Ubuka T, Kosugi T, Nozaki M, et al. Evolutionary origin of the structure and function of gonadotropin-inhibitory hormone: insights from lampreys. Endocrinology (2012) 153:2362-74. doi:10.1210/ en.2011-2046

13. Osugi T, Ubuka T, Tsutsui K. Review: evolution of GnIH and related peptides structure and function in the chordates. Front Neurosci (2014) 8:255. doi:10.3389/fnins.2014.00255

14. Nelson JS, Grande TC, Wilson MVH. Fishes of the World. 5th ed. Hoboken, NJ, USA: John Wiley \& Sons, Inc (2016). 752 p.

15. Amano M, Moriyama S, Iigo M, Kitamura S, Amiya N, Yamamori K, et al. Novel fish hypothalamic neuropeptides stimulate the release of gonadotrophins and growth hormone from the pituitary of sockeye salmon. J Endocrinol (2006) 188(3):417-23. doi:10.1677/joe.1.06494

16. Zhang Y, Li S, Liu Y, Lu D, Chen H, Huang X, et al. Structural diversity of the $\mathrm{GnIH} / \mathrm{GnIH}$ receptor system in teleost: its involvement in early development and the negative control of LH release. Peptides (2010) 31(6): 1034-43. doi:10.1016/j.peptides.2010.03.003

17. Biran J, Golan M, Mizrahi N, Ogawa S, Parhar IS, Levavi-Sivan B. LPXRFa, the piscine ortholog of $\mathrm{GnIH}$, and LPXRF receptor positively regulate gonadotropin secretion in tilapia (Oreochromis niloticus). Endocrinology (2014) 155(11):4391-401. doi:10.1210/en.2013-2047

18. Paullada-Salmerón JA, Cowan M, Aliaga-Guerrero M, Morano F, Zanuy S, Muñoz-Cueto JA. Gonadotrophin inhibitory hormone down-regulates the brain-pituitary reproductive axis of male European sea bass (Dicentrarchus labrax). Biol Reprod (2016) 94(6):121. doi:10.1095/biolreprod.116.139022

19. Moussavi M, Wlasichuk M, Chang JP, Habibi HR. Seasonal effect of GnIH on gonadotrope functions in the pituitary of goldfish. Mol Cell Endocrinol (2012) 350(1):53-60. doi:10.1016/j.mce.2011.11.020

20. Moussavi M, Wlasichuk M, Chang JP, Habibi HR. Seasonal effect of gonadotrophin inhibitory hormone on gonadotrophin-releasing hormone-induced gonadotroph functions in the goldfish pituitary. J Neuroendocrinol (2013) 25(5):506-16. doi:10.1111/jne.12024

21. Satake H, Hisada M, Kawada T, Minakata H, Ukena K, Tsutsui K. Characterization of a cDNA encoding a novel avian hypothalamic neuropeptide exerting an inhibitory effect on gonadotropin release. Biochem J (2001) 354(Pt 2):379-85. doi:10.1042/bj3540379

22. Hinuma S, Shintani Y, Fukusumi S, Iijima N, Matsumoto Y, Hosoya M, et al. New neuropeptides containing carboxy-terminal RFamide and their receptor in mammals. Nat Cell Biol (2000) 2(10):703-8. doi:10.1038/35036326

23. Ubuka T, Morgan K, Pawson AJ, Osugi T, Chowdhury VS, Minakata H, et al. Identification of human GnIH homologs, RFRP-1 and RFRP-3, and the cognate receptor, GPR147 in the human hypothalamic pituitary axis. PLoS One (2009) 4(12):e8400. doi:10.1371/journal.pone.0008400

24. Braasch I, Gehrke AR, Smith JJ, Kawasaki K, Manousaki T, Pasquier J, et al. The spotted gar genome illuminates vertebrate evolution and facilitates human-teleost comparisons. Nat Genet (2016) 48(4):427-37. doi:10.1038/ ng.3526

25. Ogawa S, Parhar IS. Structural and functional divergence of gonadotropininhibitory hormone from jawless fish to mammals. Front Endocrinol (2014) 5:177. doi: $10.3389 /$ fendo.2014.00177

26. Clarke IJ, Sari IP, Qi Y, Smith JT, Parkington HC, Ubuka T, et al. Potent action of RFamide-related peptide- 3 on pituitary gonadotropes indicative of a hypophysiotropic role in the negative regulation of gonadotropin secretion. Endocrinology (2008) 149(11):5811-21. doi:10.1210/en.2008-0575

27. Li X, Su J, Lei Z, Zhao Y, Jin M, Fang R, et al. Gonadotropin-inhibitory hormone $(\mathrm{GnIH})$ and its receptor in the female pig: cDNA cloning, expression in tissues and expression pattern in the reproductive axis during the estrous cycle. Peptides (2012) 36(2):176-85. doi:10.1016/j.peptides.2012.05.008

28. Ukena K, Koda A, Yamamoto K, Kobayashi T, Iwakoshi-Ukena E, Minakata H, et al. Novel neuropeptides related to frog growth hormone-releasing peptide: isolation, sequence, and functional analysis. Endocrinology (2003) 144(9):3879-84. doi:10.1210/en.2003-0359

29. Ukena K, Iwakoshi-Ukena E, Osugi T, Tsutsui K. Identification and localization of gonadotropin-inhibitory hormone $(\mathrm{GnIH})$ orthologs in the hypothalamus of the red-eared slider turtle, Trachemys scripta elegans. Gen Comp Endocrinol (2016) 227:69-76. doi:10.1016/j.ygcen.2015.06.009

30. Osugi T, Ukena K, Bentley GE, O’Brien S, Moore IT, Wingfield JC, et al. Gonadotropin-inhibitory hormone in Gambel's white-crowned sparrow (Zonotrichia leucophrys gambelii): cDNA identification, transcript localization and functional effects in laboratory and field experiments. J Endocrinol (2004) 182(1):33-42. doi:10.1677/joe.0.1820033

31. Ikemoto T, Park MK. Chicken RFamide-related peptide (GnIH) and two distinct receptor subtypes: identification, molecular characterization, and evolutionary considerations. J Reprod Dev (2005) 51:359-77. doi:10.1262/ jrd.16087

32. Ubuka T, Bentley GE, Ukena K, Wingfield JC, Tsutsui K. Melatonin induces the expression of gonadotropin-inhibitory hormone in the avian brain. Proc Natl Acad Sci U S A (2005) 102:3052-7. doi:10.1073/pnas.0403840102

33. Ubuka T, Kim S, Huang YC, Reid J, Jiang J, Osugi T, et al. Gonadotropininhibitory hormone neurons interact directly with gonadotropin-releasing hormone-I and -II neurons in European starling brain. Endocrinology (2008) 149(1):268-78. doi:10.1210/en.2007-0983

34. Ubuka T, Mukai M, Wolfe J, Beverly R, Clegg S, Wang A, et al. RNA interference of gonadotropin-inhibitory hormone gene induces arousal in songbirds. PLoS One (2012) 7:e30202. doi:10.1371/journal.pone.0030202

35. Kawano E, Takahata Y, Oishi T, Ukena K, Tsutsui K, Tamotsu S. Neural interaction of gonadotropin-regulating hormone immunoreactive neurons and the suprachiasmatic nucleus with the paraventricular organ in the Japanese grass lizard (Takydromus tachydromoides). Zoolog Sci (2006) 23:277-87. doi:10.2108/zsj.23.277

36. Koda A, Ukena K, Teranishi H, Ohta S, Yamamoto K, Kikuyama S, et al. A novel amphibian hypothalamic neuropeptide: isolation, localization, and biological activity. Endocrinology (2002) 143:411-9. doi:10.1210/endo. 143.2.8630

37. Chartrel N, Dujardin C, Leprince J, Desrues L, Tonon MC, Cellier E, et al. Isolation, characterization, and distribution of a novel neuropeptide, Rana RFamide (R-RFa), in the brain of the European green frog Rana esculenta. J Comp Neurol (2002) 448:111-27. doi:10.1002/cne.10253

38. Chowdhury VS, Ubuka T, Osugi T, Shimura T, Tsutsui K. Identification, localization and expression of LPXRFamide peptides, and melatonin-dependent induction of their precursor mRNA in the newt brain. J Endocrinol (2011) 209:211-20. doi:10.1530/JOE-10-0494

39. Jadhao AG, Pinelli C, D’Aniello B, Tsutsui K. Gonadotropin-inhibitory hormone $(\mathrm{GnIH})$ in the amphibian brain and its relationship with the gonadotropin releasing hormone (GnRH) system: an overview. Gen Comp Endocrinol (2017) 240:69-76. doi:10.1016/j.ygcen.2016.09.006

40. Ubuka T, Son YL, Bentley GE, Millar RP, Tsutsui K. Gonadotropin-inhibitory hormone (GnIH), GnIH receptor and cell signaling. Gen Comp Endocrinol (2013) 190:10-7. doi:10.1016/j.ygcen.2013.02.030

41. Paullada-Salmerón JA, Cowan M, Aliaga-Guerrero M, Gómez A, Zanuy S, Mañanos E, et al. LPXRFa peptide system in the European sea bass: a molecular and immunohistochemical approach. J Comp Neurol (2016) 524(1):176-98. doi:10.1002/cne.23833

42. Ogawa S, Sivalingam M, Biran J, Golan M, Anthonysamy RS, Levavi-Sivan B, et al. Distribution of LPXRFa, a gonadotropin-inhibitory hormone ortholog peptide, and LPXRFa receptor in the brain and pituitary of the tilapia. J Comp Neurol (2016) 524(14):2753-75. doi:10.1002/cne.23990

43. Biswas S, Jadhao AG, Pinelli C, Palande NV, Tsutsui K. GnIH and GnRH expressions in the central nervous system and pituitary of Indian major carp, Labeo rohita during ontogeny: an immunocytochemical study. Gen Comp Endocrinol (2015) 220:88-92. doi:10.1016/j.ygcen.2014.06.005

44. Di Yorio MP, Pérez Sirkin DI, Delgadin TH, Shimizu A, Tsutsui K, Somoza GM, et al. Gonadotropin-inhibitory hormone in the cichlid fish Cichlasoma dimerus: structure, brain distribution and differential effects on the secretion of gonadotropins and growth hormone. J Neuroendocrinol (2016) 28:5. doi:10.1111/jne.12377

45. Saito TH, Nakane R, Akazome Y, Abe H, Oka Y. Electrophysiological analysis of the inhibitory effects of FMRFamide-like peptides on the pacemaker activity of gonadotropin-releasing hormone neurons. J Neurophysiol (2010) 104(6):3518-29. doi:10.1152/jn.01027.2009

46. Akazome Y, Yamamoto E, Oka Y. SAT-298: ligand dose-dependent switch in G-protein coupling (Gi and Gs) of medaka (Oryzias latipes) neuropeptide 
FF receptors, NPFFR1 (GPR147) and NPFFR2 (GPR74). Endocrine Society's 97th Annual Meeting and Expo; Mar 7; San Diego (2015).

47. Corchuelo S, Martinez ERM, Butzge AJ, Doretto LB, Ricci JMB, Valentin FN, et al. Characterization of $\mathrm{Gnrh} / \mathrm{Gnih}$ elements in the olfacto-retinal system and ovary during zebrafish ovarian maturation. Mol Cell Endocrinol (2017) 450:1-13. doi:10.1016/j.mce.2017.04.002

48. Spicer OS, Zmora N, Wong TT, Golan M, Levavi-Sivan B, Gothilf Y, et al. The gonadotropin-inhibitory hormone (Lpxrfa) system's regulation of reproduction in the brain-pituitary axis of the zebrafish (Danio rerio). Biol Reprod (2017) 96(5):1031-42. doi:10.1093/biolre/iox032

49. Zohar Y, Muñoz-Cueto JA, Elizur A, Kah O. Neuroendocrinology of reproduction in teleost fish. Gen Comp Endocrinol (2010) 165(3):438-55. doi:10.1016/j.ygcen.2009.04.017

50. Escobar S, Felip A, Gueguen MM, Zanuy S, Carrillo M, Kah O, et al. Expression of kisspeptins in the brain and pituitary of the European sea bass (Dicentrarchus labrax). J Comp Neurol (2013) 521(4):933-48. doi:10.1002/ cne. 23211

51. Johnson MA, Tsutsui K, Fraley GS. Rat RFamide-related peptide-3 stimulates GH secretion, inhibits LH secretion, and has variable effects on sex behavior in the adult male rat. Horm Behav (2007) 51(1):171-80. doi:10.1016/j.yhbeh. 2006.09.009

52. Bentley GE, Perfito N, Ukena K, Tsutsui K, Wingfield JC. Gonadotropininhibitory peptide in song sparrows (Melospiza melodia) in different reproductive conditions, and in house sparrows (Passer domesticus) relative to chicken-gonadotropin-releasing hormone. J Neuroendocrinol (2003) 15: 794-802. doi:10.1046/j.1365-2826.2003.01062.x

53. Poling MC, Quennell JH, Anderson GM, Kauffman AS. Kisspeptin neurones do not directly signal to RFRP-3 neurones but RFRP-3 may directly modulate a subset of hypothalamic kisspeptin cells in mice. J Neuroendocrinol (2013) 25:876-86. doi:10.1111/jne.12084

54. Small TW, Sharp PJ, Bentley GE, Millar RP, Tsutsui K, Deviche P. Photoperiodindependent hypothalamic regulation of luteinizing hormone secretion in a free-living Sonoran desert bird, the rufous-winged sparrow (Aimophila carpalis). Brain Behav Evol (2007) 71(2):127-42. doi:10.1159/000111459

55. Cowan M, Paullada-Salmerón JA, López-Olmeda JF, Sánchez-Vázquez FJ, Muñoz-Cueto JA. Effects of pinealectomy on the neuroendocrine reproductive system and locomotor activity in male European sea bass, Dicentrarchus labrax. Comp Biochem Physiol A Mol Integr Physiol (2017) 207:1-12. doi:10.1016/j.cbpa.2017.02.008

56. Anglade I, Zandbergen T, Kah O. Origin of the pituitary innervation in the goldfish. Cell Tissue Res (1993) 273(2):345-55. doi:10.1007/BF00312837

57. Qi X, Zhou W, Li S, Lu D, Yi S, Xie R, et al. Evidences for the regulation of GnRH and GTH expression by GnIH in the goldfish, Carassius auratus. Mol Cell Endocrinol (2013) 366:9-20. doi:10.1016/j.mce.2012.11.001

58. Shahjahan M, Ikegami T, Osugi T, Ukena K, Doi H, Hattori A, et al. Synchronised expressions of LPXRFamide peptide and its receptor genes: seasonal, diurnal and circadian changes during spawning period in grass puffer. J Neuroendocrinol(2011)23(1):39-51.doi:10.1111/j.1365-2826.2010.02081.x

59. Qi X, Zhou W, Lu D, Wang Q, Zhang H, Li S, et al. Sexual dimorphism of steroidogenesis regulated by $\mathrm{GnIH}$ in the goldfish, Carassius auratus. Biol Reprod (2013) 88(89):8177. doi:10.1095/biolreprod.112.105114

60. Choi YJ, Kim NN, Habibi HR, Choi CY. Effects of gonadotropin inhibitory hormone or gonadotropin-releasing hormone on reproduction-related genes in the protandrous cinnamon clownfish, Amphiprion melanopus. Gen Comp Endocrinol (2016) 235:89-99. doi:10.1016/j.ygcen.2016.06.010

61. Sari IP, Rao A, Smith JT, Tilbrook AJ, Clarke IJ. Effect of RF-amide-related peptide- 3 on luteinizing hormone and follicle-stimulating hormone synthesis and secretion in ovine pituitary gonadotropes. Endocrinology (2009) 150:5549-56. doi:10.1210/en.2009-0775

62. Shahjahan M, Doi H, Ando H. LPXRFamide peptide stimulates growth hormone and prolactin gene expression during the spawning period in the grass puffer, a semi-lunar synchronized spawner. Gen Comp Endocrinol (2016) 227:77-83. doi:10.1016/j.ygcen.2015.09.008

63. Moussavi M, Wlasichuk M, Chang JP, Habibi HR. Seasonal effects of GnIH on basal and GnRH-induced goldfish somatotrope functions. J Endocrinol (2014) 223(2):191-202. doi:10.1530/JOE-14-0441

64. Wang Q, Qi X, Guo Y, Li S, Zhang Y, Liu X, et al. Molecular identification of $\mathrm{GnIH} / \mathrm{GnIHR}$ signal and its reproductive function in protogynous hermaphroditic orange-spotted grouper (Epinephelus coioides). Gen Comp Endocrinol (2015) 216:9-23. doi:10.1016/j.ygcen.2015.04.016

65. Wang Q, Qi X, Tang H, Guo Y, Li S, Li G, et al. Molecular identification of StAR and 3BHSD1 and characterization in response to GnIH stimulation in protogynous hermaphroditic grouper (Epinephelus coioides). Comp Biochem Physiol B Biochem Mol Biol (2017) 206:26-34. doi:10.1016/j.cbpb.2017.01.001

66. Paullada-Salmerón JA, Cowan M, Aliaga-Guerrero M, López-Olmeda JF, Mañanós EL, Zanuy S, et al. Testicular steroidogenesis and locomotor activity are regulated by gonadotropin-inhibitory hormone in male European sea bass. PLoS One (2016) 11(10):e0165494. doi:10.1371/journal.pone.0165494

67. Bentley GE, Ubuka T, McGuire NL, Chowdhury VS, Morita Y, Yano T, et al. Gonadotropin-inhibitory hormone and its receptor in the avian reproductive system. Gen Comp Endocrinol (2008) 156(1):34-43. doi:10.1016/j.ygcen.2007.10.003

68. Maddineni SR, Ocon-Grove OM, Krzysik-Walker SM, Hendricks GR, Ramachandran R. Gonadotropin-inhibitory hormone $(\mathrm{GnIH})$ receptor gene is expressed in the chicken ovary: potential role of $\mathrm{GnIH}$ in follicular maturation. Reproduction (2008) 135(2):267-74. doi:10.1530/REP-07-0369

69. McGuire NL, Kangas K, Bentley GE. Effects of melatonin on peripheral reproductive function: regulation of testicular $\mathrm{GnIH}$ and testosterone. Endocrinology (2011) 152(9):3461-70. doi:10.1210/en.2011-1053

70. Singh P, Krishna A, Tsutsui K. Effects of gonadotropin-inhibitory hormone on folliculogenesis and steroidogenesis of cyclic mice. Fertil Steril (2011) 95(4):1397-404. doi:10.1016/j.fertnstert.2010.03.052

71. Ancel C, Bentsen AH, Sebert ME, Tena-Sempere M, Mikkelsen JD, Simonneaux V. Stimulatory effect of RFRP-3 on the gonadotrophic axis in the male Syrian hamster: the exception proves the rule. Endocrinology (2012) 153(3):1352-63. doi:10.1210/en.2011-1622

72. Bentley GE, Jensen JP, Kaur GJ, Wacker DW, Tsutsui K, Wingfield JC. Rapid inhibition of female sexual behavior by gonadotropin-inhibitory hormone (GnIH). Horm Behav (2006) 49:550-5. doi:10.1016/j.yhbeh.2005.12.005

73. Ubuka T, Haraguchi S, Tobari Y, Narihiro M, Ishikawa K, Hayashi T, et al. Hypothalamic inhibition of socio-sexual behaviour by increasing neuroestrogen synthesis. Nat Commun (2014) 5:3061. doi:10.1038/ncomms4061

74. Piekarski DJ, Zhao S, Jennings KJ, Iwasa T, Legan SJ, Mikkelsen JD, et al. Gonadotropin-inhibitory hormone reduces sexual motivation but not lordosis behavior in female Syrian hamsters (Mesocricetus auratus). Horm Behav (2013) 64:501-10. doi:10.1016/j.yhbeh.2013.06.006

75. Sánchez-Vázquez FJ, Azzaydi M, Martínez-López FJ, Zamora S, Madrid JA. Annual rhythms of demand-feeding activity in sea bass: evidence of a seasonal phase inversion of the diel feeding pattern. Chronobiol Int (1998) 15(6):607-22. doi:10.3109/07420529808993197

76. Villamizar N,Herlin M,LópezMD, Sánchez-VázquezFJ. Daily spawning andlocomotor activity rhythms of European sea bass broodstock (Dicentrarchus labrax). Aquaculture (2012) 35(4-355):117-20. doi:10.1016/j.aquaculture.2012.03.028

77. Cerdá-Reverter JM, Muriach B, Zanuy S, Muñoz-Cueto JA. A cytoarchitectonic study of the brain of a perciform species, the sea bass (Dicentrarchus labrax): the midbrain and hindbrain. Acta Histochem (2008) 110(6):433-50. doi:10.1016/j.acthis.2008.01.001

78. Parhar IS, Ogawa S, Ubuka T. Reproductive neuroendocrine pathways of social behavior. Front Endocrinol (2016) 31(7):28. doi:10.3389/fendo.2016.00028

79. Black MP, Balthazart J, Baillien M, Grober MS. Socially induced and rapid increases in aggression are inversely related to brain aromatase activity in a sex-changing fish, Lythrypnus dalli. Proc Biol Sci (2005) 272(1579):2435-40. doi:10.1098/rspb.2005.3210

80. Huffman LS, O'Connell LA, Hofmann HA. Aromatase regulates aggression in the African cichlid fish Astatotilapia burtoni. Physiol Behav (2013) 11(2-113):77-83. doi:10.1016/j.physbeh.2013.02.004

81. Hallgren SL, Linderoth M, Olsén KH. Inhibition of cytochrome p450 brain aromatase reduces two male specific sexual behaviours in the male Endler guppy (Poecilia reticulata). Gen Comp Endocrinol (2006) 147:323-8. doi:10.1016/j.ygcen.2006.02.005

82. Kriegsfeld LJ, Ubuka T, Bentley GE, Tsutsui K. Seasonal control of gonadotropin-inhibitory hormone ( $\mathrm{GnIH})$ in birds and mammals. Front Neuroendocrinol (2015) 37:65-75. doi:10.1016/j.yfrne.2014.12.001

83. Tsutsui K, Ubuka T, Bentley GE, Kriegsfeld LJ. Review: regulatory mechanisms of gonadotropin-inhibitory hormone $(\mathrm{GnIH})$ synthesis and release in photoperiodic animals. Front Neurosci (2013) 7:60. doi:10.3389/fnins. 2013.00060 
84. Bayarri MJ, Rol de Lama MA, Madrid JA, Sánchez-Vázquez FJ. Both pineal and lateral eyes are needed to sustain daily circulating melatonin rhythms in sea bass. Brain Res (2003) 969(1-2):175-82. doi:10.1016/S00068993(03)02297-2

85. Falcón J, Migaud H, Muñoz-Cueto JA, Carrillo M. Current knowledge on the melatonin system in teleost fish. Gen Comp Endocrinol (2010) 165(3): 469-82. doi:10.1016/j.ygcen.2009.04.026

86. Herrera-Pérez P, Rendón MC, Besseau L, Sauzet S, Falcón J, Muñoz-Cueto JA. Melatonin receptors in the brain of the European sea bass: an in situ hybridization and autoradiographic study. J Comp Neurol (2010) 518(17):3495-511. doi: $10.1002 /$ cne. 22408

87. Ekström P, van Veen T. Pineal neural connections with the brain in two teleosts, the crucian carp and the European eel. J Pineal Res (1984) 1(3): 245-61. doi:10.1111/j.1600-079X.1984.tb00216.x

88. Servili A, Herrera-Pérez P, Yáñez J, Muñoz-Cueto JA. Afferent and efferent connections of the pineal organ in the European sea bass Dicentrarchus labrax: a carbocyanine dye tract-tracing study. Brain Behav Evol (2011) 78(4):272-85. doi:10.1159/000330824

89. Servili A, Lethimonier C, Lareyre JJ, López-Olmeda JF, SánchezVázquez FJ, Kah $\mathrm{O}$, et al. The highly conserved gonadotropin-releasing hormone-2 form acts as a melatonin-releasing factor in the pineal of a teleost fish, the European sea bass Dicentrarchus labrax. Endocrinology (2010) 151(5):2265-75. doi:10.1210/en.2009-1207

90. Ando H, Shahjahan M, Hattori A. Molecular neuroendocrine basis of lunar-related spawning in grass puffer. Gen Comp Endocrinol (2013) 181: 211-4. doi:10.1016/j.ygcen.2012.07.027

91. Bayarri MJ, Zanuy S, Yilmaz O, Carrillo M. Effects of continuous light on the re-productive system of European sea bass gauged by alterations of circadian variations during their first reproductive cycle. Chronobiol Int (2009) 26(2):184-99. doi:10.1080/07420520902758311

92. Espigares F, Rocha A, Molés G, Gómez A, Carrillo M, Zanuy S. New insights into the factors mediating the onset of puberty in sea bass. Gen Comp Endocrinol (2015) 224:176-85. doi:10.1016/j.ygcen.2015.08.013

93. Navarro-Martín L, Viñas J, Ribas L, Díaz N, Gutiérrez A, Di Croce L, et al. DNA methylation of the gonadal aromatase (cyp19a) promoter is involved in temperature-dependent sex ratio shifts in the European sea bass. PLoS Genet (2011) 7(12):e1002447. doi:10.1371/journal.pgen.1002447

94. Rodríguez L, Carrillo M, Sorbera LA, Soubrier MA, Mañanos E, Holland MC, et al. Pituitary levels of three forms of $\mathrm{GnRH}$ in the male European sea bass (Dicentrarchus labrax, L.) during sex differentiation and first spawning season. Gen Comp Endocrinol (2000) 120(1):67-74. doi:10.1006/gcen.2000.7533

95. Paullada-Salmerón JA, Loentgen GH, Cowan M, Aliaga-Guerrero M, Rendón-Unceta MC, Muñoz-Cueto JA. Developmental changes and day-night expression of the gonadotropin-inhibitory hormone system in the European sea bass: effects of rearing temperature. Comp Biochem Physiol A Mol Integr Physiol (2017) 206:54-62. doi:10.1016/j.cbpa.2017.01.009

96. Piferrer F, Blázquez M, Navarro L, González A. Genetic, endocrine, and environmental components of sex determination and differentiation in the European sea bass (Dicentrarchus labrax L.). Gen Comp Endocrinol (2005) 142(1-2):102-10. doi:10.1016/j.ygcen.2005.02.011

97. Ubuka T, Ueno M, Ukena K, Tsutsui K. Developmental changes in gonadotropin-inhibitory hormone in the Japanese quail (Coturnix japonica) hypothalamo-hypophysial system. J Endocrinol (2003) 178(2):311-8. doi:10.1677/joe.0.1780311

98. Peragine DE, Pokarowski M, Mendoza-Viveros L, Swift-Gallant A, Cheng HM, Bentley GE, et al. RFamide-related peptide-3 (RFRP-3) suppresses sexual maturation in a eusocial mammal. Proc Natl Acad Sci U S A (2017) 114(5): 1207-12. doi:10.1073/pnas.1616913114

99. Tsutsui K, Ubuka T, Son YL, Bentley GE, Kriegsfeld LJ. Contribution of $\mathrm{GnIH}$ research to the progress of reproductive neuroendocrinology. Front Endocrinol (2015) 6:179. doi:10.3389/fendo.2015.00179

100. Kirby ED, Geraghty AC, Ubuka T, Bentley GE, Kaufer D. Stress increases putative gonadotropin inhibitory hormone and decreases luteinizing hormone in male rats. Proc Natl Acad Sci U S A (2009) 106(27):11324-9. doi:10.1073/pnas.0901176106

101. Son YL, Ubuka T, Narihiro M, Fukuda Y, Hasunuma I, Yamamoto K, et al. Molecular basis for the activation of gonadotropin-inhibitory hormone gene transcription by corticosterone. Endocrinology (2014) 155:1817-26. doi:10.1210/en.2013-2076

102. Choi YJ, Habibi HR, Kil GS, Jung MM, Choi CY. Effect of cortisol on gonadotropin inhibitory hormone $(\mathrm{GnIH})$ in the cinnamon clownfish, Amphiprion melanopus. Biochem Biophys Res Commun (2017) 485(2):342-8. doi:10.1016/j.bbrc.2017.02.078

Conflict of Interest Statement: The authors declare that the research was conducted in the absence of any commercial or financial relationships that could be construed as a potential conflict of interest.

Copyright (c) 2017 Muñoz-Cueto, Paullada-Salmerón, Aliaga-Guerrero, Cowan, Parhar and Ubuka. This is an open-access article distributed under the terms of the Creative Commons Attribution License (CC BY). The use, distribution or reproduction in other forums is permitted, provided the original author(s) or licensor are credited and that the original publication in this journal is cited, in accordance with accepted academic practice. No use, distribution or reproduction is permitted which does not comply with these terms. 